$$
\begin{gathered}
\text { UNIVERSIDADE DE SÃO PAULO } \\
\text { ESCOLA DE ENGENHARIA DE SÃO CARLOS } \\
\text { DEPARTAMENTO DE GEOTECNIA }
\end{gathered}
$$

\title{
UTILIZAÇÃO DE PENETRÔMETRO MANUAL EM SOLO COLAPSÍVEL E COMPARAÇÃO COM RESULTADOS DE PROVAS DE CARGA EM PLACA E EM SAPATA
}

CRISTINA DE HOLLANDA CAVALCANTI TSUHA

Dissertação apresentada à Escola de Engenharia de São Carlos, da Universidade de São Paulo, como parte dos requisitos para obtenção do Título de Mestre em Geotecnia

ORIENTADOR: PROF. DR. JOSÉ CARLOS A. CINTRA 
AGRADECIMENTOS

Ao Professor José Carlos A. Cintra que, com sua orientação, paciência e amizade, contribuiu para o aperfeiçoamento deste trabalho.

A todos os colegas, especialmente a Érika Sá e ao Domingos Borges, aos professores, e aos funcionários do Departamento de Geotecnia da USP/São Carlos, pelo apoio, amizade e colaboração. 


\section{RESUMO}

TSUHA, C. H. C. (2003). Utilização de Penetrômetro Manual em Solo Colapsível e Comparação com Resultados de Provas de Carga em Placa e em Sapata. Dissertação (Mestrado) - Escola de Engenharia de São Carlos, Universidade de São Paulo, São Carlos, 2003.

O presente trabalho tem como objetivo avaliar a utilização de um penetrômetro manual para quantificar a resistência à penetração em um solo poroso e não-saturado. Os ensaios foram efetuados com monitoração de sucção, obtendo-se assim correlações entre resistência à penetração do penetrômetro e a sucção do solo. Os valores de tensão de ruptura obtidos nos ensaios penetrométricos foram comparados com valores de capacidade de carga de ensaios de placa e de provas de carga em sapatas realizados à mesma profundidade, no mesmo local, com medidas simultâneas de sucção. Finalmente, o trabalho comprova a influência da sucção nos resultados dos ensaios realizados.

Palavras-chave: penetrômetro; prova de carga; capacidade de carga; sucção 


\begin{abstract}
TSUHA, C. H. C. (2003). The Utilization of a hand penetrometer in a collapsible soil and comparison with load tests in plate and in footing Dissertação (Mestrado) - Escola de Engenharia de São Carlos, Universidade de São Paulo, São Carlos, 2003.
\end{abstract}

The objective of this work is to evaluate the use of a hand penetrometer to quantify the penetration resistance of a porous and unsaturated soil. The tests were done with suction monitoring, thus, it was obtained correlation between resistance of the penetrometer penetration and the soil suction. The values of rupture pressure obtained by the penetrometer tests were compared with values of bearing capacity of plate load tests and footing load tests, that were done at the same deep and at the same location, with suction measurement. Finally, this work proves the influence of the suction on the tests results.

Key-words: penetrometer; load test; bearing capacity; suction 


\section{SUMÁRIO}

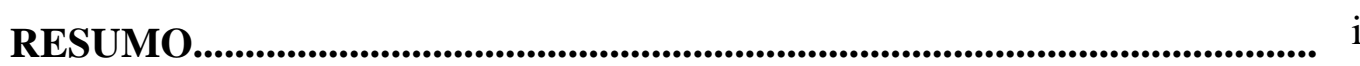

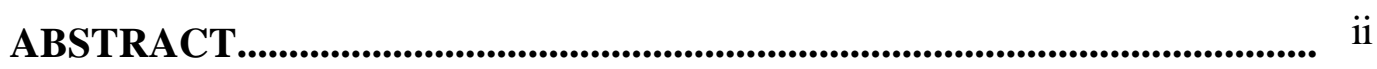

LISTA DE FIGURAS....................................................................................

LISTA DE TABELAS........................................................................... vi

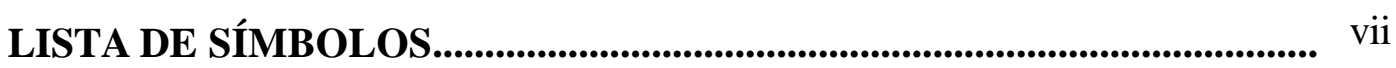

1 - INTRODUÇÃ O............................................................................................... 1

2 - REVISÃO BIBLIOGRÁFICA........................................................................ 3

2.1 - INTRODUÇÃ̃

2.2 - PENETRÔMETRO MANUAL .......................................................... 3

2.2.1 - Generalidades.................................................................. 3

2.2.2 - Exemplos de Aplicação de Penetrômetro Manua 1......................... 6

2.3 - CONTROLE DE CAPACIDADE DE CARGA............................ 11 DE FUNDAÇÕES DIRETAS

2.4 - PROVA DE CARGA SOBRE PLACA............................................. 12

2.4.1 - Instalação e execução da prova de carga...................................... 13

2.4 .2 - Interpretação dos resultados.................................................. 15

2.4.2.1 - Critério de Terzaghi...................................................... 16

2.4.2.2 - Tensão de "pré-adensame nto".......................................... 17

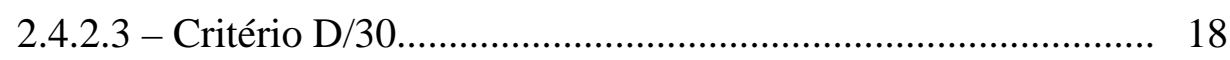

2.5 - SOLOS COLAPSÍVEIS..................................................................... 20

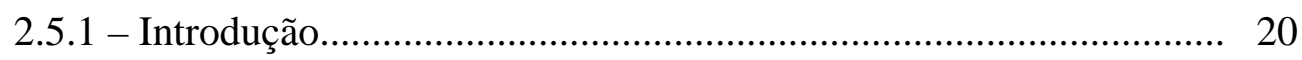


2.5.2 - Influência da Sucção

3 - MATERIAIS E MÉTODOS......................................................................... 26

3.1 - INTRODUÇÃ O............................................................................... 26

3.2 - CAMPO EXPERIMENTAL ......................................................................... 26

3.2.1 - Características Geológicas...................................................... 26

3.2.2 - Locação dos Ensaios............................................................... 28

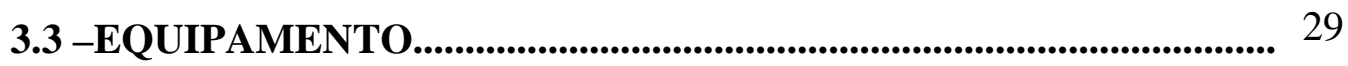

3.3.1 - Equipamento Utilizado....................................................... 29

3.3.2 - Adaptações.......................................................................... 30

3.4 - PROCEDIMENTOS DE ENSAIO........................................................ 32

3.4.1 - Monitoração da Sucção.............................................................. 32

3.4.2 - Ensaio Penetromético............................................................ 33

4 - RESULTADOS OBTIDOS E ANÁLISE........................................................ 37

4.1 - INTRODUÇÃ

4.2 -RESULTADOS.................................................................................. 38

4.3- ANÁLISE DOS RESULTADOS............................................................ 41

4.3.1 - Tensão de Ruptura do Ensaio Penetrométrico............................... 41

4.3.2 - Variação da Tensão de Ruptura com a Sucção.............................. 41

4.3.3 - Comparação com Placas de Diâmetro 0,80 m............................... 42

4.3.4 - Comparação com Sapatas de Diâmetro 1,50 m.............................. 46

4.3.5 - Comparação entre Placa e Sapata.................................................... 49

4.3.6 - Influência da Colapsibilidade................................................... 50

5 - CONCLUSÕES E RECOMENDAÇÕES................................................... 51

REFERÊNCIAS BIBLIOGRÁFICAS..................................................... 54

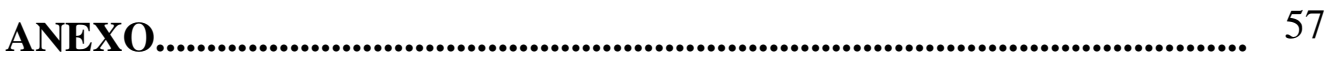




\section{LISTA DE FIGURAS}

FIGURA 2.1 - $\quad$ Aparelho manual de Barentsen (AOKI, 1973)

FIGURA 2.2 - Conjunto tubo-haste do penetrômetro (AOKI, 6 1973)

FIGURA 2.3 - Detalhes do penetrômetro (LOBO et al, 1994) 7

FIGURA 2.4 - $\quad$ Esquema de execução do ensaio (LOBO et al, $\quad 8$ 1994)

FIGURA 2.5 - Variação do SPT e NGP com a profundidade 8 (LOBO et al, 1994)

FIGURA 2.6 - Relação entre SPT e NGP (LOBO et al, 1994) 9

FIGURA 2.7 - Penetrômetro dinâmico leve $\left(\begin{array}{llll}10 & \mathrm{~kg} & \text { tipo } & 10\end{array}\right.$ Maquesonda) e ponteira (CASTELLO et al, 2001)

FIGURA 2.8 - Tipos de ensaios de placa quanto à localização, ao tipo de placa e ao modo de carregamento (VELLOSO \& LOPES, 1996)

FIGURA 2.9 - Cuidados na interpretação dos ensaios de placa: diferentes bulbos de pressão (VELLOSO \& LOPES, 1996)

FIGURA 2.10 - Curvas típicas tensão x recalque (TERZAGHI, 1943)

FIGURA 2.11 - Curva típica log tensão $\mathrm{x}$ recalque (MACACARI, 2001)

FIGURA 2.12 - Conceito básico de recalque adicional devido ao colapso da estrutura do solo (JENNINGS \& KNIGHT, 1975 apud CINTRA, 1998)

FIGURA 2.13 - Uso de sapatas em solo colapsível compactado 
FIGURA 2.14 - Ocorrência de colapso em prova de carga realizada com inundação do solo durante o ensaio (CINTRA, 1998)

FIGURA 2.15 - Prova de carga em solo colapsível previamente inundado (CINTRA, 1998)

FIGURA 2.16 - Variação da tensão de ruptura de sapatas corridas em função da sucção matricial (FREDLUND \& RAHARDJO, 1993)

FIGURA 2.17 - Curvas tensão x recalque de provas de carga sobre placa em solo não-saturado com diferentes sucções (COSTA, 1999)

FIGURA 2.18 - Influência da sucção e da profundidade na capacidade de carga (MACACARI, 2001)

FIGURA 3.1 - Perfil geotécnico representativo do Campo Experimental (AOKI, 2000)

FIGURA 3.2 - Esquema de locação das cavas ensaiadas com penetrômetro

FIGURA 3.3 - Penetrômetro de solos - marca Solotest ref.1.210.001

FIGURA 3.4 - Anel dinamométrico com capacidade de $1 \mathrm{KN}$ 30

FIGURA $3.5-\quad$ Régua da haste do penetrômetro

FIGURA 3.6 - Placa de borracha do penetrômetro

FIGURA 3.7 - Instalação de tensiômetros no local do ensaio para monitoração da sucção do solo

FIGURA 3.8 - Locação dos pontos ensaiados pelo 35 penetrômetro no interior de cada cava

FIGURA 3.9 - Realização do ensaio com o penetrômetro (1) 36

FIGURA 3.10 - Realização do ensaio com o penetrômetro (2) 36

FIGURA 4.1 - $\quad$ Resistência média x penetração em função da 40 sucção

FIGURA 4.2 - Tensão de ruptura do ensaio penetrométrico $\left(\mathrm{q}_{\mathrm{p}}\right) \times \operatorname{sucção}(\psi)$ 
FIGURA 4.3 - Curvas "tensão x recalque" de dois ensaios inundados em placa de 0,80 m (COSTA, 1999)

FIGURA 4.4 - Curvas "tensão x recalque" de três ensaios em placa de $0,80 \mathrm{~m}$, com as sucções médias de 15 , 22 e $33 \mathrm{kPa}$ (COSTA, 1999)

FIGURA 4.5 - Tensão de ruptura em ensaios de penetração $\left(\mathrm{q}_{\mathrm{p}}\right)$ x capacidade de carga $\left(\sigma_{\mathrm{r}}\right)$ em ensaios de placa de $\phi 0,80 \mathrm{~m}$, para um mesmo nível de sucção

FIGURA 4.6 - Curvas "tensão x recalque" de três provas de carga em sapata de diâmetro $1,50 \mathrm{~m}$, com as sucções médias de 0, 21 e $23 \mathrm{kPa}$ (VIANNA \& CINTRA, 2003)

FIGURA 4.7 - Tensão de ruptura do penetrômetro $\left(\mathrm{q}_{\mathrm{p}}\right) \mathrm{x}$ 48 capacidade de carga $\left(\sigma_{\mathrm{r}}\right)$ do sistema sapatasolo, para uma mesma sucção 


\section{LISTA DE TABELAS}

TABELA 1 - Resistência à penetração de $10 \mathrm{~cm}$ do penetrômetro na cava teste $(\mathrm{R}, \mathrm{em} \mathrm{kN})$

TABELA 2 - Sucção média em cada cava na data de ensaio

TABELA 3 - Valores de resistência do solo à penetração do penetrômetro ( $\mathrm{R}$ em $\mathrm{kPa}$ ) em cavas de $0,50 \mathrm{~m}$

TABELA 4 - Valores de resistência do solo à penetração do penetrômetro ( $\mathrm{R}$ em $\mathrm{kPa}$ ) em cavas de $0,60 \mathrm{~m}$

TABELA 5 - Valores de resistência do solo à penetração do penetrômetro ( $\mathrm{R}$ em $\mathrm{kPa}$ ) em cavas de $1,70 \mathrm{~m}$

TABELA 6 - Valor médio de resistência em três profundidades diferentes

TABELA 7 - Valores estimados de tensão de ruptura em ensaios de penetração $\left(\mathrm{q}_{\mathrm{p}}\right)$ correspondentes aos valores de sucção $(\psi)$

TABELA 8 - Capacidade de carga $\left(\sigma_{\mathrm{r}}\right)$ em ensaios de placa em função da sucção

TABELA 9 - Valores de sucção e de $\mathrm{q}_{\mathrm{p}}$ medidos no mesmo dia das provas de carga em sapata

TABELA 10 - Valores de capacidade de carga $\left(\sigma_{\mathrm{r}}\right)$ em provas de carga em sapatas de 1,50 m de diâmetro em função da sucção

TABELA 11 - Valores de $q_{p}$ (tensão de ruptura em ensaio de penetração) e 49 de $\sigma_{\mathrm{r}}$ (capacidade de carga em provas de carga em placa de $0,80 \mathrm{~m}$ e sapata de $1,50 \mathrm{~m}$ ) para diferentes valores de sucção 


\section{LISTA DE SÍMBOLOS}

D - Diâmetro da placa

$\sigma_{\mathrm{a}}-$ Tensão admissível

$\sigma_{\mathrm{r}}-$ Capacidade de carga

$\psi$ - Sucção

R - Resistência à penetração do penetrômetro

$\phi$ - Diâmetro da cava

$q_{p}$ - Tensão de ruptura do ensaio penetrométrico 


\section{INTRODUÇÃO}

Usualmente, a capacidade de carga de fundações diretas é controlada por meio da experiência do engenheiro geotécnico, aliada ao resultado das investigações geotécnicas disponíveis.

Após a abertura de cavas para fundações rasas ou poços para tubulões, a conduta mais utilizada pelo engenheiro geotécnico é a introdução no solo de uma barra de aço com 12,5 $\mathrm{mm}$ de diâmetro, proporcionando assim uma estimativa qualitativa da resistência do solo à penetração desta barra, que é comparada com o tipo de solo identificado pela sondagem mais próxima.

Neste procedimento, se o solo observado satisfizer as condições adotadas em projeto, as cavas ou poços serão liberados para execução do elemento estrutural da fundação. No caso do solo não apresentar a resistência esperada, serão efetuadas mudanças na profundidade ou na dimensão da fundação.

Deste modo, no controle de capacidade de carga de fundações diretas, a barra de aço é a ferramenta utilizada na tomada de decisão do engenheiro, para possibilitar sua intervenção durante a execução da fundação.

Por meio desta conduta, não é quantificada a resistência à penetração da barra. Assim, esse procedimento é válido apenas devido à experiência do engenheiro geotécnico, que tendo tido contato anteriormente com uma diversidade de resistência de solos à penetração da barra de aço, juntamente com as sondagens próximas aos poços examinados, e observando as características geotécnicas do subsolo que irá suportar a estrutura a ser executada, têm a sensibilidade de julgar se as cavas ou poços apresentam as condições exigidas no projeto de fundações.

Esse procedimento foi utilizado, na prática, pela autora desta dissertação, quando trabalhou em consultoria de fundações, por três anos. Nessa atividade profissional, foi inspecionado um grande número de cavas e poços para sapatas e tubulões. Constatourse que a utilização da barra de aço constitui um procedimento empírico, em que a experiência adquirida fica difícil de ser transmitida. 
Uma alternativa pode ser a utilização de penetrômetros portáteis, que permitem a obtenção de um valor quantitativo da resistência do solo na cota inspecionada.

São encontrados no mercado modelos de penetrômetros portáteis estáticos e dinâmicos, sendo que somente para o segundo tipo existem trabalhos publicados na literatura geotécnica.

Para esta pesquisa, foi escolhido um modelo de penetrômetro estático com anel dinamométrico, que é capacitado a medir tensões de até $1550 \mathrm{kPa}$.

O objetivo do presente trabalho é avaliar a utilização desse modelo de penetrômetro portátil, como forma de quantificar a resistência em função da sucção em um solo colapsível, e também, comparar os resultados obtidos nos ensaios penetrométricos com os resultados de provas de carga em placa e em sapata, com monitoração por tensiômetros. 
CAPÍTULO 02

\section{REVISÃO BIBLIOGRÁFICA}

\section{1 - INTRODUÇÃO}

Neste capítulo apresenta-se a revisão da literatura relacionada a penetrômetros, inspeção do solo para fundações diretas, ensaios de placa, e solos colapsíveis.

\section{2 - PENETRÔMETRO}

Conforme o GLOSSÁRIO DE EQUIPAMENTOS DE SONDAGENS da ABGE (1980), penetrômetro é um instrumento que tem por finalidade fornecer índices sobre a resistência que o solo oferece à sua penetração. Consiste em um tubo ou uma ponteira maciça, conectada às hastes, e introduzido no solo através de pressão de um macaco hidráulico (penetração estática) ou de golpes de peso de cravação (penetração dinâmica).

\subsection{1 - GENERALIDADES}

Segundo RÖHM (1984), a penetração de uma haste no terreno é uma técnica que vem sendo utilizada há muito tempo para se obter medidas de resistência das camadas de um terreno. Engenheiros e arquitetos valiam-se da introdução de varas de madeira ou hastes metálicas no solo já no início do século XIX com o objetivo de comparar locais construídos com outros a serem explorados, baseados na resistência oferecida pelo terreno à introdução da sonda. A evolução deste processo rudimentar deu origem aos penetrômetros hoje usados principalmente na obtenção de informações da subsuperfície em locais onde a amostragem ou outros tipos de determinações tornam-se difíceis ou até mesmo impossíveis, economicamente inviáveis, ou ainda incompatíveis com o ritmo de construção de uma obra. Basicamente o equipamento consiste de uma haste metálica munida de uma ponta que pode ser introduzida no terreno através de um processo 
dinâmico ou estático. No penetrômetro dinâmico a energia necessária para efetuar a penetração do conjunto haste-ponta é obtida a partir da queda livre de uma massa sobre um elemento solidário à haste. No penetrômetro estático a energia necessária para efetuar a penetração do conjunto haste-ponta é obtida a partir de sistemas tais como macacos hidráulicos, coroa-pinhão, correntes e outros.

BONDARIK (1967) alega que as determinações das propriedades do solo, examinado penetrometricamente, são baseadas no fato de que a resistência à penetração apresentada pelo solo é função de suas características geotécnicas (apud RÖHM, 1984).

AOKI (1973) cita que os primeiros ensaios realizados com um penetrômetro manual datam do período 1932/1937, quando BARENTSEN, na Holanda, inventou o sistema tubo de revestimento - haste - cone, patenteado em 1938, sob no 43095, com a denominação de penetrômetro manual (Figura 2.1).

O aparelho manual de BARENTSEN consiste, em princípio, de um pequeno cone de aço com ângulo de $60^{\circ}$ no vértice e uma área de base de $10 \mathrm{~cm}^{2}$, fixado a uma haste de aço por meio da qual o cone pode ser introduzido no solo a uma dada velocidade. Para eliminar o atrito entre o solo e a haste, esta última é envolvida por um tubo de revestimento que se fecha na parte inferior, de tal sorte que, o solo não possa aí penetrar. A haste e o tubo podem ser prolongados por meio de peças de 1,0 $\mathrm{m}$ de comprimento. Os tubos são ligados entre si por meio de roscas e, dentro dos tubos, as hastes são colocadas ponta a ponta, cada uma excedendo o tubo de revestimento em cerca de $8,5 \mathrm{~cm}$. Em seguida, o cone, a haste e o tubo são cravados até a profundidade desejada, por um ou dois homens, por meio de um dispositivo de prensagem de quatro braços colocado sobre o tubo de revestimento (AOKI, 1973).

A resistência do solo sob a ponta cone faz com que a base deste seja mantida contra o tubo de revestimento durante a fase da cravação. A resistência do solo sobre a ponta do cone é então medida pela simples prensagem da haste que transmite a carga ao solo, por meio do cone. A operação é efetuada por meio de um dispositivo (macaco hidráulico), provido de cabo, colocado sobre a haste interna. Exercendo-se uma força sobre o cabo, o líquido dentro do cilindro é comprimido pelo pistão, sendo a pressão aplicada registrada por um manômetro acoplado ao dispositivo. A pressão no óleo sobe até o momento em que a descida do cone se inicia. A leitura deve ser feita no momento em que o cone desce e o valor (máximo), assim registrado, é a resistência de ponta (valor medido). No instante da cravação, os olhos do operador devem estar fixos no manômetro, a fim de se ler a pressão. $\mathrm{O}$ cone é cravado cerca de $8 \mathrm{~cm}$. A operação se 
repete na prática a cada $20 \mathrm{~cm}$ ou mais. Sendo o diâmetro do pistão igual ao diâmetro da base do cone, o valor lido no manômetro é dado diretamente em unidades de tensão. Esta leitura deverá ser corrigida face às influências do peso do cone, da haste e do dispositivo de aplicação de carga (AOKI, 1973).

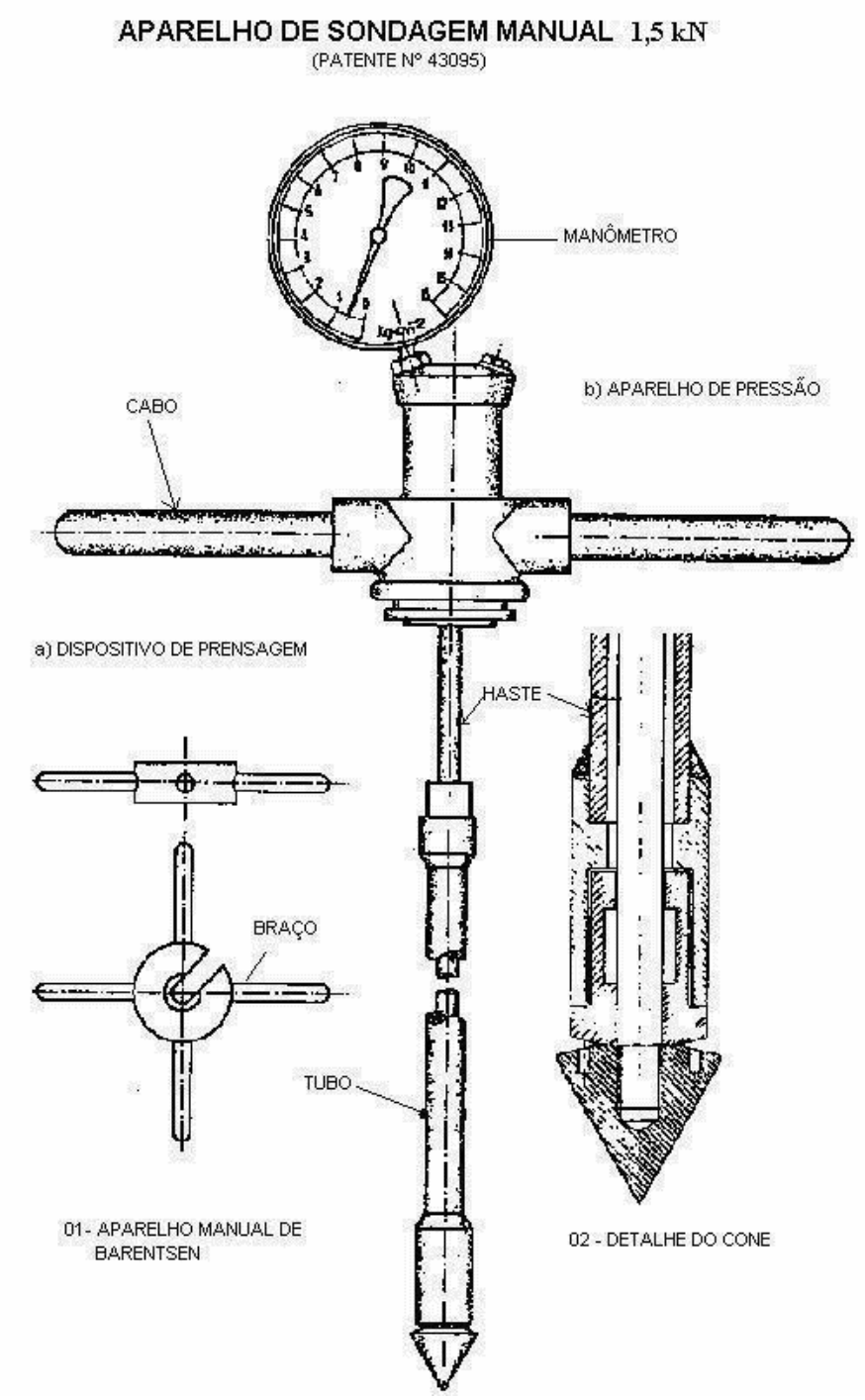

FIGURA 2.1 - Aparelho manual de Barentsen (AOKI, 1973)

Para se conhecer a resistência do terreno “in situ’ procede-se a cravação de um tubo de revestimento provido de uma haste interna terminando em forma de cone (Figura 2.2). 


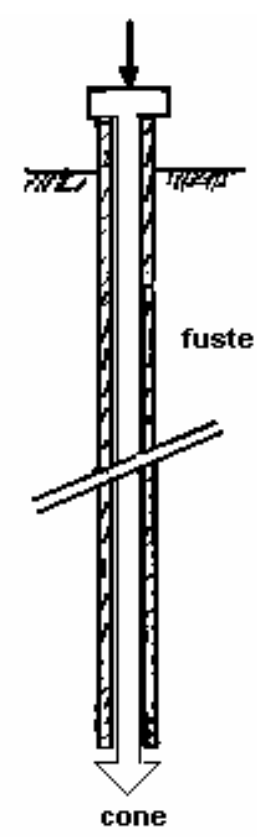

FIGURA 2.2 - Conjunto tubo-haste do penetrômetro (AOKI, 1973)

Mede-se a resistência de ponta fazendo-se avançar o cone pela aplicação de uma força sobre a haste interna, permanecendo fixo o tubo de revestimento (fuste). Aplicando-se a carga sobre o tubo de revestimento, pode-se fazer o conjunto penetrar no terreno sendo, então, medida a resistência total. Trata-se, portanto, de um ensaio realizado sobre uma estaca de pequeno diâmetro, que permite conhecer a tensão de ruptura na ponta e o valor de atrito lateral entre o fuste e o terreno adjacente (AOKI, 1973).

\subsection{2 - EXEMPLOS DE APLICAÇÃO DE PENETRÔMETRO MANUAL}

$\mathrm{Na}$ literatura, foram encontrados somente estudos sobre a utilização de penetrômetro manual dinâmico.

O trabalho de LOBO et al. (1994) apresenta resultados de ensaios de cravação de penetrômetro de aço, com forma cônica, portátil e classificado como leve (Figura 2.3). 


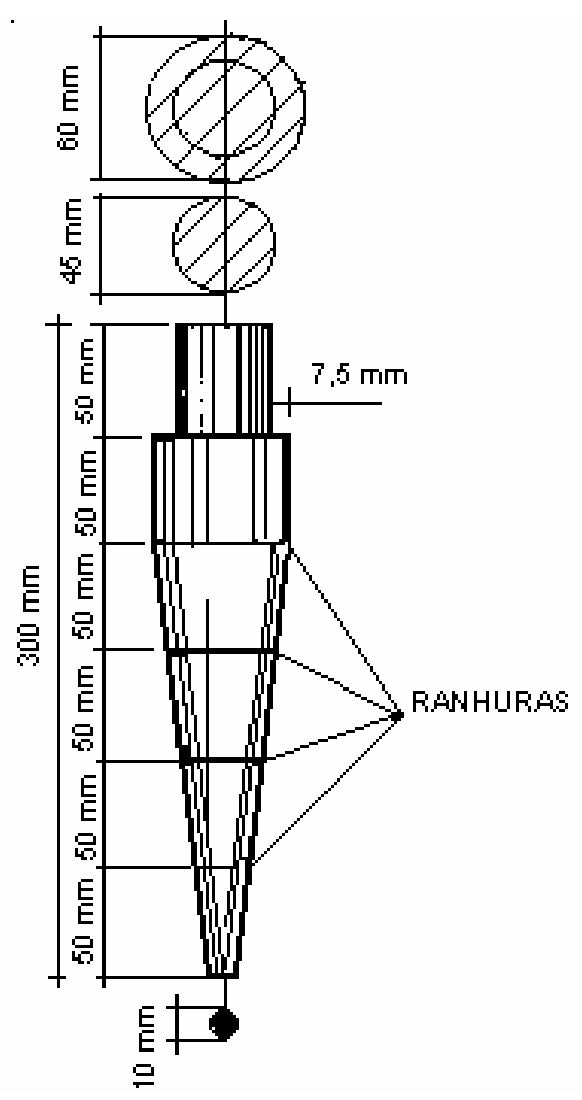

FIGURA 2.3 - Detalhes do penetrômetro (LOBO et al., 1994)

Nesse trabalho, foram escolhidos três pontos aleatórios no fundo da escavação do tubulão. Em cada ponto foi cravado manualmente o penetrômetro no solo (Figura 2.4), até a primeira marca de $50 \mathrm{~mm}$. Posteriormente, com a utilização do soquete padronizado do ensaio de compactação modificado (massa de 4,5 kg e altura de queda de $45 \mathrm{~cm}$ ) o penetrômetro foi cravado por mais $100 \mathrm{~mm}$. O número de golpes necessário para essa cravação foi chamado de NGP (Número de Golpes do Penetrômetro). 


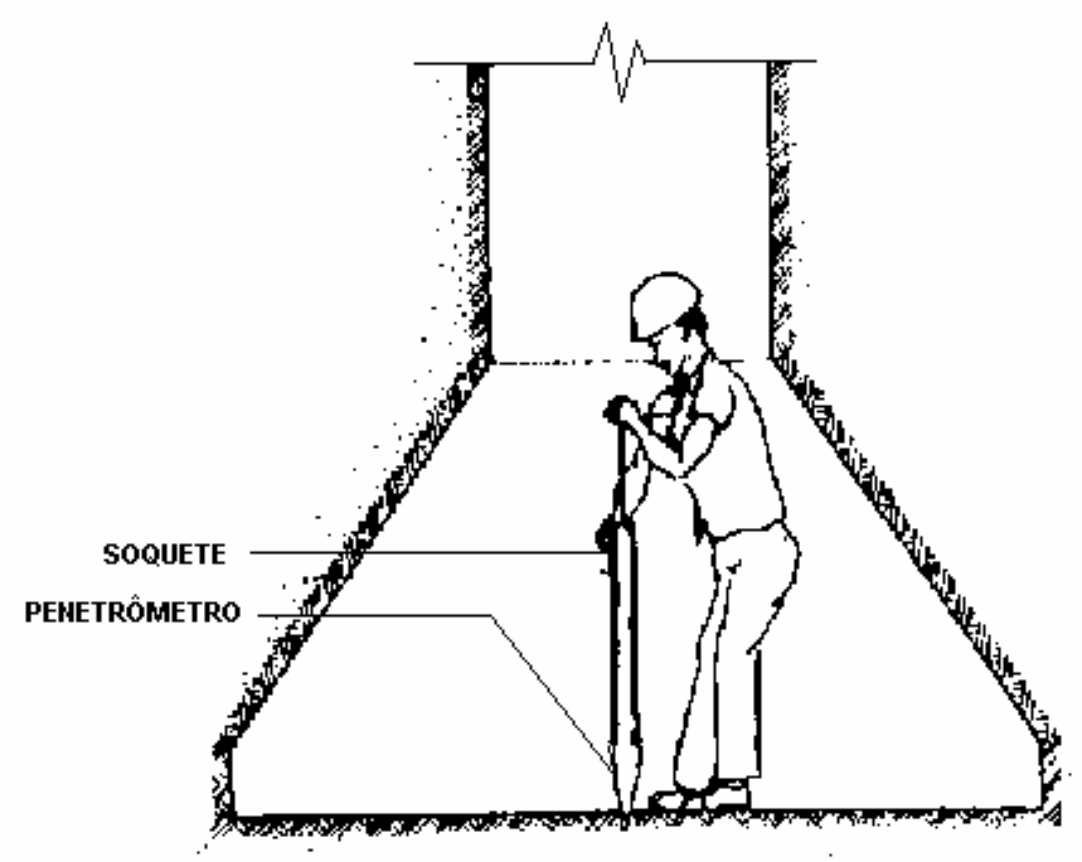

FIGURA 2.4 - Esquema de execução do ensaio (LOBO et al., 1994)

Para LOBO et al. (1994), as boas correlações obtidas (Figuras 2.5 e 2.6) entre os valores de NGP e SPT (índice de resistência à penetração de sondagem a percussão), mais a simplicidade e rapidez na execução do ensaio indicam que esse penetrômetro poderá constituir uma ferramenta bastante útil para os engenheiros geotécnicos, na confirmação da cota de apoio de bases de tubulões.

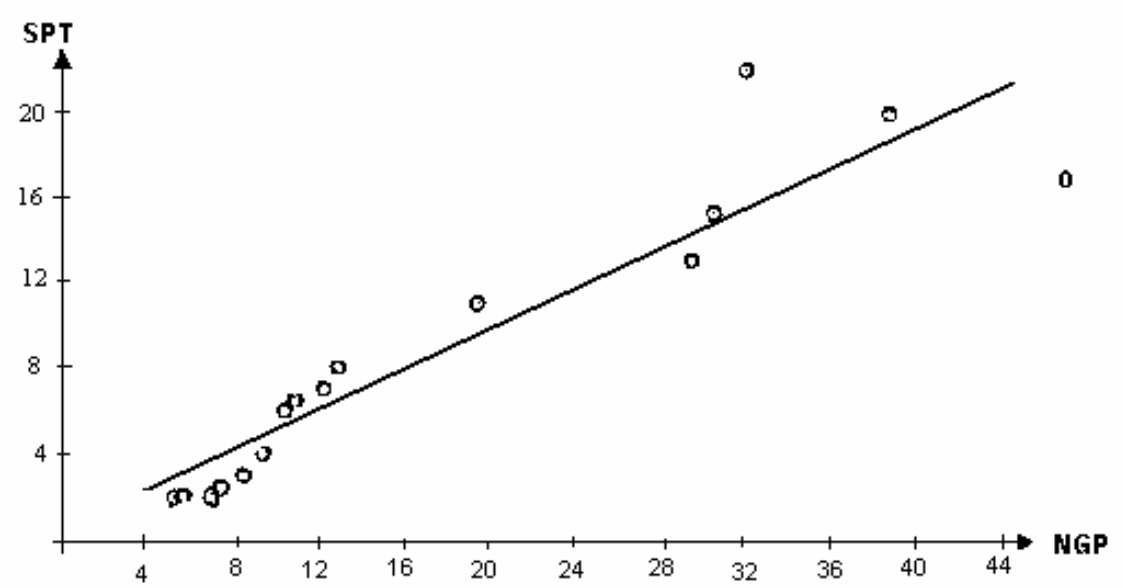

FIGURA 2.5 - Variação do SPT e NGP com a profundidade (LOBO et al., 1994) 


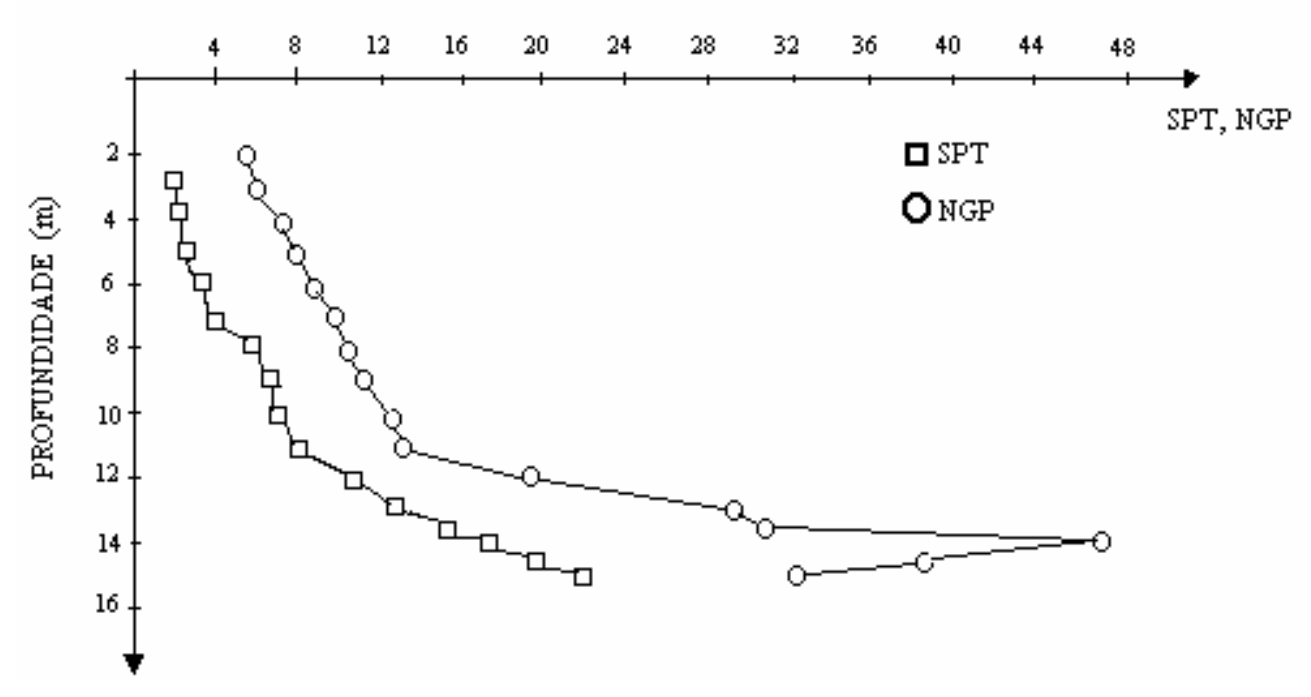

FIGURA 2.6 - Relação entre SPT e NGP (LOBO et al., 1994)

Segundo LOBO et al. (1996), encontrada a correlação entre NGP e SPT, a partir do SPT mínimo de projeto para apoio da base, encontra-se o valor mínimo do NGP para que se possa autorizar a concretagem da base do tubulão.

CASTELLO et al. (2001) utilizam para o caso de fundação por sapatas em uma obra na cidade de São Paulo, um penetrômetro dinâmico leve que é comercializado no Brasil pela Maquesonda (Figura 2.7). O penetrômetro usado na obra é especificado na "Referência Internacional para Procedimentos de Ensaio para Sondagem Dinâmica (DP)" (ISS-MFE,1989). Consiste basicamente numa haste com ponta rombuda que é penetrada no solo por golpes. A ponta rombuda tem por objetivo criar um vazio no solo e minimizar a ocorrência de atrito ou aderência ao longo das hastes. Na referência especificam-se quatro tipos de penetrômetro, desde um com martelo de $10 \mathrm{~kg}$, queda de $0,5 \mathrm{~m}$ e ponta de $35,7 \pm 0,3 \mathrm{~mm}$ de diâmetro até um com martelo de $63,5 \mathrm{~kg}$, queda $0,75 \mathrm{~m}$ e ponta de $51 \pm 0,5 \mathrm{~mm}$ de diâmetro, e ainda admite outros tipos de equipamentos. A ponteira é cravada no solo de $10 \mathrm{em} 10 \mathrm{~cm}$ até $30 \mathrm{~cm}$ e mede-se o número de golpes para a cravação. As hastes devem ser giradas de metro em metro ou menos, e o torque medido para se estimar o atrito lateral. Sua resistência de ponta $\mathrm{q}_{\mathrm{d}}$, é obtida por meio da fórmula dinâmica para estacas:

$$
\mathrm{q}_{\mathrm{d}}=\left(\mathrm{M} / \mathrm{M}+\mathrm{M}^{\prime}\right) \mathrm{x}(\mathrm{MgH} / \mathrm{Ae})
$$


em que:

$\mathrm{q}_{\mathrm{d}}=$ valores de resistência de ponta em termos de tensão;

$\mathrm{M}=$ Massa do martelo;

M' = Massa total das hastes, da cabeça de bater e pinos-guia;

$\mathrm{H}=$ Altura de queda do martelo;

e = Penetração média por golpe;

$\mathrm{A}=$ Área da base do cone;

$\mathrm{g}=$ Aceleração da gravidade

A resistência de ponta $\mathrm{q}_{\mathrm{d}}$ é comparável à resistência de ponta do cone, segundo WASCHKOWSKY (1983). No entanto, como não se tem no Brasil nenhum estudo que confirme as conclusões de WASCHKOWSKY, em cada obra faz-se uma "calibração" do penetrômetro comparando-os com valores de SPT (CASTELLO et al., 2001).
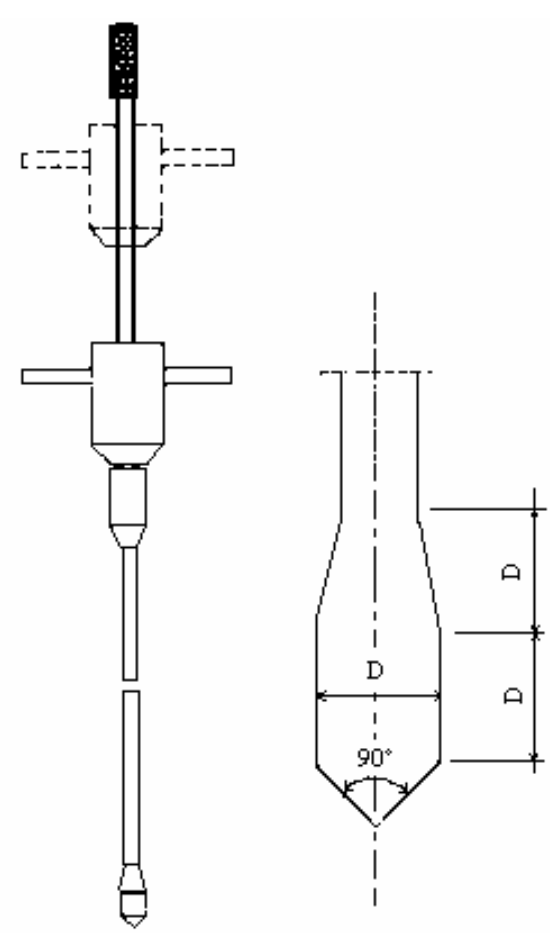

FIGURA 2.7 - Penetrômetro dinâmico leve (10 kg, tipo Maquesonda) e ponteira (CASTELLO et al., 2001) 


\section{3 - INSPEÇÃO DO SOLO PARA FUNDAÇÕES DIRETAS}

Segundo GODOY \& TEIXEIRA (1996), para estimar-se a tensão admissível de uma fundação em sapatas, provas de carga em placa são pouco usadas, ainda que se apresentem como uma alternativa importante para o estudo da compressibilidade de areias, argilas fissuradas e, principalmente, de solos residuais. As maiores dificuldades práticas do seu emprego residem no tempo necessário para a sua execução e na dificuldade de acesso à camada de interesse, numa época em que edifícios rotineiramente têm dois subsolos de garagem (apoio de sapatas a 7-8 m de profundidade, freqüentemente abaixo do nível d'água). Ensaios “in situ” mais modernos como pressiômetro Menard, o dilatômetro Marchetti e outros ainda não estão incorporados à prática de fundações brasileiras.

De acordo com LOBO et al. (1994), a inspeção da cota de apoio da base de tubulões tem sido feita de forma empírica pelo profissional que desce até o fundo do poço e verifica se as condições do solo estão adequadas para a tensão admissível adotada em projeto.

LOBO et al. (1996) relatam que a liberação da cota para bertura da base alargada de tubulões tem sido feito de modo empírico e pessoal. É comum o projetista ou o profissional encarregado da liberação para abertura da base utilizar apenas uma barra de aço de construção, ou uma espátula para "auscultar" o solo, obtendo, no entanto, apenas indicações qualitativas das características do solo.

Conforme GODOY \& TEIXEIRA (1996), uma das vantagens da investigação por um poço exploratório é que este permite aferir a "firmeza" dos solos usando "penetrômetro" manual (barra de aço de $\phi$ 12,5 mm).

No procedimento de penetração da barra de aço no solo, deve-se levar em conta também, que a resistência à penetração da barra varia com o tipo de solo, e não somente com o número de golpes do SPT. Comparando a penetração de uma barra em solo arenoso e em solo argiloso com o mesmo número de golpes do SPT, observa-se que a areia é muito mais resistente à penetração da barra.

Existem no mercado aparelhos denominados penetrômetros, que são utilizados na inspeção de cavas e poços para fundações diretas, que indicam uma ordem de grandeza da resistência à penetração no solo. No entanto, a utilização da barra de aço é a conduta mais comum. 
Na ABNT e na ASTM não se encontram especificados procedimentos de inspeção do solo de apoio de fundações diretas.

\section{4 - PROVA DE CARGA SOBRE PLACA}

Conforme GODOY \& TEIXEIRA (1996), a prova de carga sobre placa se constitui na realidade em ensaio em modelo reduzido de uma sapata. Ela nasceu antes das conceituações da Mecânica dos Solos, aplicada empiricamente na tentativa de obtenção de informações sobre o comportamento tensão-deformação de um determinado solo de fundação. Porém, devido à pequena dimensão da placa, apenas o solo situado imediatamente abaixo da placa é solicitado durante uma prova de carga.

De acordo com a Norma Brasileira para Projeto e Execução de Fundações (NBR 6122, 1996), a prova de carga sobre placa representa um dos critérios, para determinação da tensão admissível de fundações diretas.

Segundo VELLOSO \& LOPES (1996) os tipos de ensaio de placa são os seguintes:

a) Quanto à localização (Figura 2.8 a):

- na superfície;

- em cavas;

em furos.

b) Quanto ao tipo de placa (Figura 2.8 b):

- placa convencional;

- placa-parafuso ("screw-plate"), desenvolvida por JANBU \& SENNESET (1973).

c) Quanto ao modo de carregamento (Figura $2.8 \mathrm{c}-\mathrm{e}$ ):

- carga controlada;

- carga incremental mantida por períodos de tempo preestabelecidos ou até a quase estabilização (Figura 2.8 d);

- carga cíclica com diferentes padrões de ciclagem (Figura 2.8 e). 
- deformação controlada, com diferentes velocidades (Figura 2.8 c).
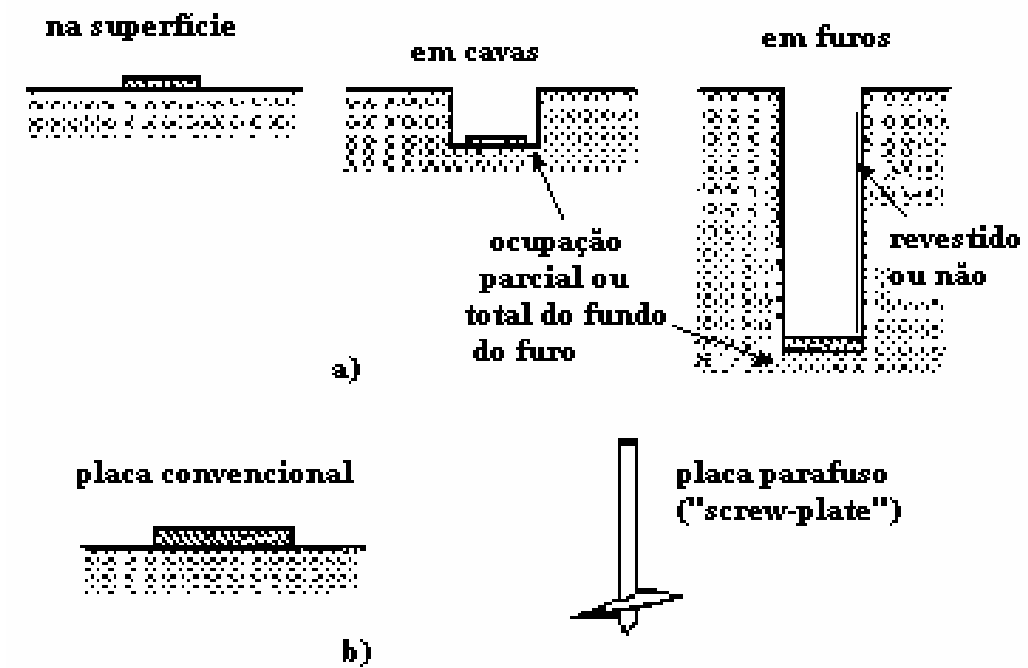

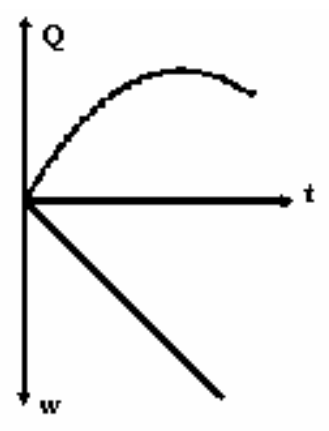

(c)

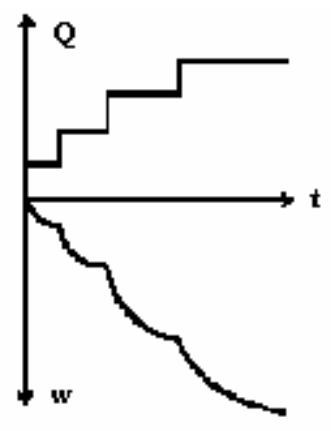

(d)

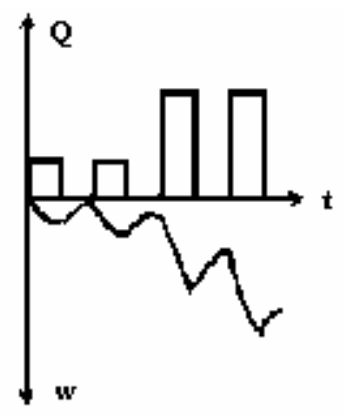

(e)

FIGURA 2.8 - Tipos de ensaio de placa quanto (a) à localização, (b) ao tipo de placa e (c) - (e) ao modo de carregamento (VELLOSO \& LOPES, 1996)

\subsection{1 - INSTALAÇÃO E EXECUÇÃO DA PROVA DE CARGA}

Conforme a Norma Brasileira para Prova de Carga Direta sobre Terreno de Fundação (NBR 6489, 1984), a instalação de uma prova de carga direta deve-se proceder como segue:

a) A cota da superfície de carga deverá, sempre, ser a mesma que das eventuais bases das sapatas da futura fundação;

b) A placa para a aplicação das cargas ao solo deverá ser rígida e terá uma área não inferior a $0,5 \mathrm{~m}^{2}$, e será colocada sobre o solo em seu estado natural e devidamente 
nivelado, ocupando a área total do fundo de um poço. A relação entre a largura e a profundidade do poço para a prova, deve ser a mesma que entre a largura e a profundidade da futura fundação;

c) Ao abrir-se o poço, todos cuidados serão necessários para evitar alteração do grau de umidade natural e amolgamento do solo na superfície de carga;

d) Em torno da placa de prova (ou poço) o terreno deverá ser aplainado, e não deverão existir cargas aplicadas a ele dentro de uma faixa de largura, pelo menos igual ao diâmetro ou lado da placa;

e) dispositivo de transmissão de carga deve ser tal que a mesma seja aplicada verticalmente, no centro da placa, e de modo a não produzir choques ou trepidações. É aconselhado o uso de macaco hidráulico munido de bomba e manômetro devidamente afe ridos, reagindo contra uma carga de reação.

f) Os recalques deverão ser medidos por extensômetros sensíveis a 0,01 mm colocados em dois pontos diametralmente opostos da placa;

g) Os dispositivos de referência para medidas de recalque deverão estar livres da influência dos movimentos da placa, do terreno circunvizinho, do caixão ou das ancoragens, devem seus apoios achar-se a uma distância igual a, pelo menos, 1,5 vezes o diâmetro ou lado da placa, medida a partir do centro desta última;

h) As trepidações de qualquer espécie devem ser evitadas durante a execução das provas de carga.

Para a execução da prova de carga deve-se observar o seguinte processo:

a) A carga aplicada à placa em estágios sucessivos de no máximo, 20\% da taxa admissível provável do solo;

b) Em cada estágio de carga, os recalques serão lidos imediatamente após a aplicação dessa carga e após intervalos de tempo sucessivamente dobrados (1, 2, 4, 8, 15 minutos, etc.). Só será aplicado novo acréscimo de carga depois de verificada a estabilização dos recalques (com tolerância máxima de 5\% do recalque total nesse estágio, entre leituras sucessivas);

c) ensaio deverá ser levado até, pelo menos, observar-se um recalque total de $25 \mathrm{~mm}$ ou até atingir-se o dobro da taxa admitida para o solo;

d) A carga máxima alcançada no ensaio, caso não se vá até a ruptura, deverá ser mantida, pelo menos, durante 12 horas; 
e) A descarga deverá ser feita em estágios sucessivos, não superiores a $25 \%$ da carga total, lendo-se os recalques de maneira idêntica à do carregamento e mantendo-se cada estágio até a estabilização dos recalques, dentro da pressão admitida.

\subsection{2 - INTERPRETAÇÃO DOS RESULTADOS}

Como resultado do ensaio será apresentada uma curva tensão-recalque em que devem figurar as observações feitas no início e fim de cada estágio de carga, com indicação dos tempos decorridos.

VELLOSO \& LOPES (1996) citam alguns cuidados muito importantes que devem ser tomados na execução e interpretação dos ensaios de placa:

- Heterogeneidade: caso haja estratificação do terreno, os resultados do ensaio poderão indicar muito pouco do que acontecerá à fundação real (Figura 2.9);

- Presença de lençol d'água: segundo TERZAGHI \& PECK (1948/1967), por exemplo, o recalque de placas em areias submersas pode ser até duas vezes maior que em areias secas ou úmidas;

- Drenagem parcial: em solos argilosos, dependendo do critério de estabilização, pode estar ocorrendo adensamento e, assim, o recalque observado estará entre instantâneo e o final ou drenado;

- Não linearidade da curva carga-recalque: mesmo na parte inicial da curva cargarecalque (trecho de interesse no caso de uma interpretação com vistas a recalques), pode haver uma forte não linearidade, e pode haver mudança de comportamento quando o carregamento atinge a tensão de pré-adensamento (ou de pré-compressão). 


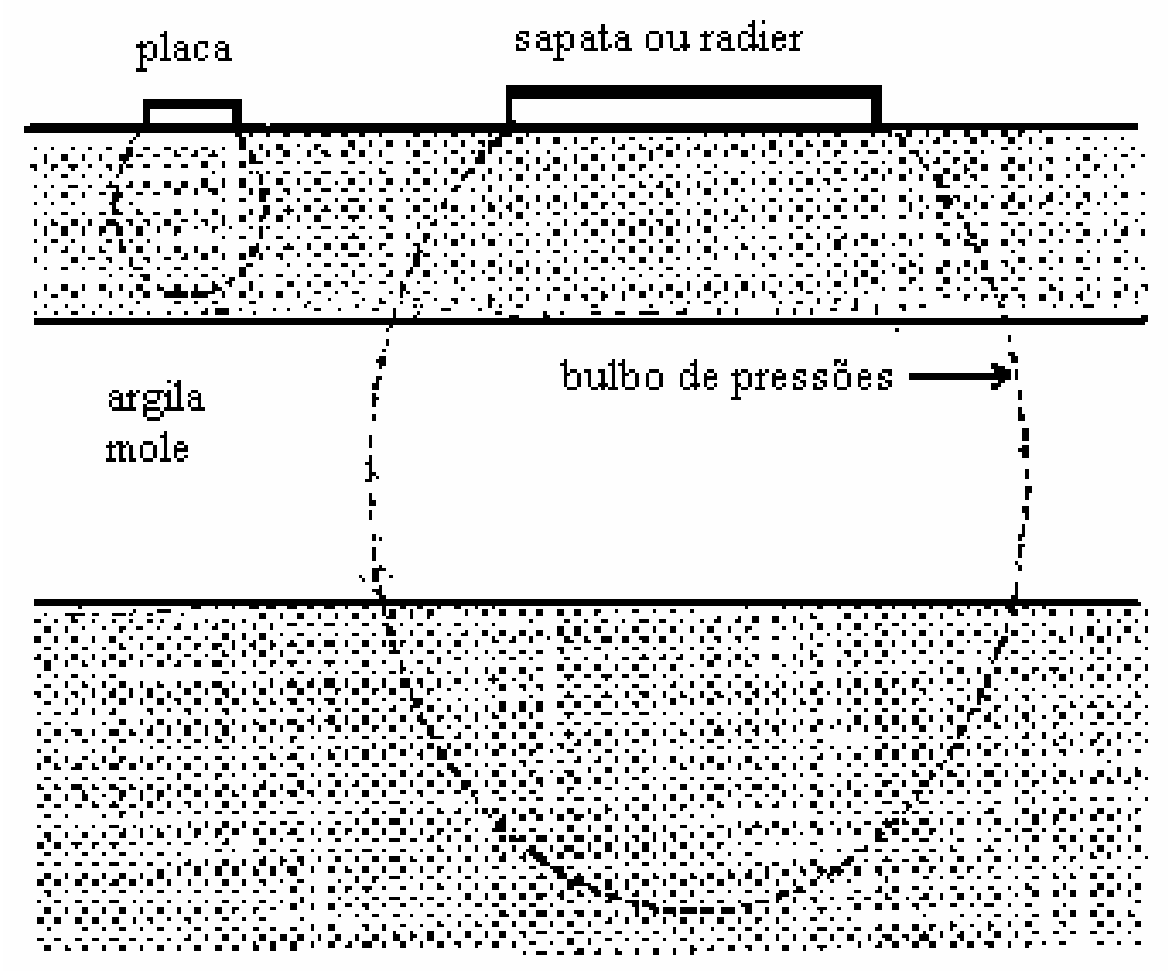

FIGURA 2.9 - Cuidados na interpretação dos ensaios de placa: diferentes bulbos de pressão (VELLOSO \& LOPES, 1996)

\subsubsection{1 - CRITÉRIO DE TERZAGHI}

TERZAGHI (1943) definiu dois modos de ruptura do maciço de solo, ilustrados através de curvas típicas, $\mathrm{C}_{1}$ e $\mathrm{C}_{2}$, da relação tensão x recalque na Figura 2.10. A curva $\mathrm{C}_{1}$ representa a relação tensão $\mathrm{x}$ recalque para solos compactos ou rijos, e a curva $\mathrm{C}_{2}$ para solos fofos ou moles. Para solos compactos ou rijos $\left(\mathrm{C}_{1}\right)$ a ruptura é caracterizada pela abscissa $\sigma_{\mathrm{r}}$ da tangente vertical à curva. Para solos fofos ou moles $\left(\mathrm{C}_{2}\right)$, a tensão de ruptura $\sigma_{\mathrm{r}}^{\prime}$ corresponde ao ponto em que a curva tensão x recalque passa a exibir um comportamento linear. 


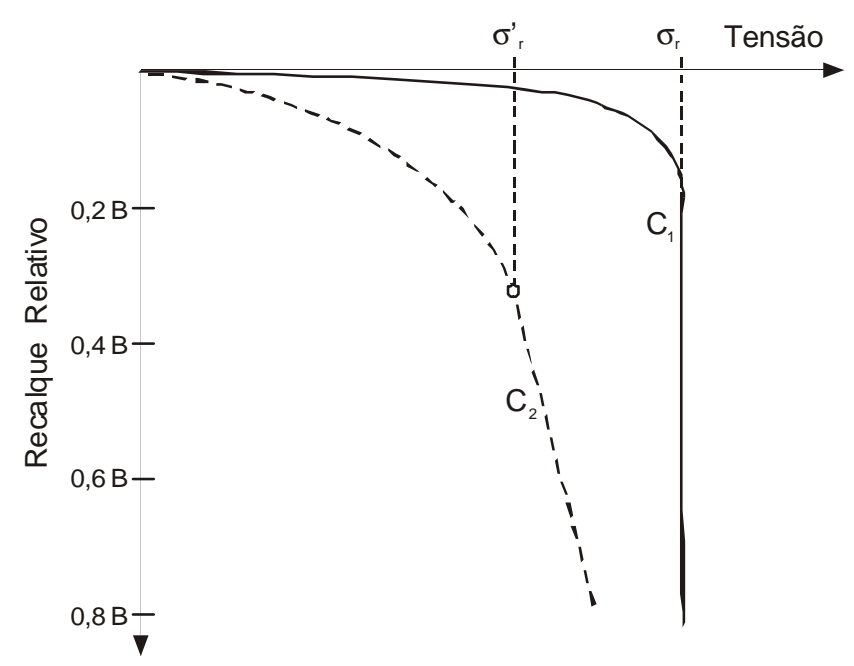

FIGURA 2.10 - Curvas típicas tensão x recalque (TERZAGHI, 1943)

\subsubsection{2 -TENSÃO DE “PRÉ -ADENSAMENTO”}

Conforme o procedimento utilizado por MACACARI (2001), ao passar o eixo das tensões para a escala logarítmica, observa-se que o gráfico log tensão x recalque tem certa semelhança com a curva índice de vazios (e) $\mathrm{x} \log$ tensão de ensaios de adensamento de solos argilosos saturados. Por isso, pode-se determinar a tensão que corresponde a uma espécie de tensão de pré-adensamento.

Assim, obtém-se a curva log tensão x recalque para o ensaio da placa, ilustrada pela Figura 2.11 e aplica-se, por exemplo, o critério de PACHECO SILVA (1970) para a determinação da "tensão de pré-adensamento".

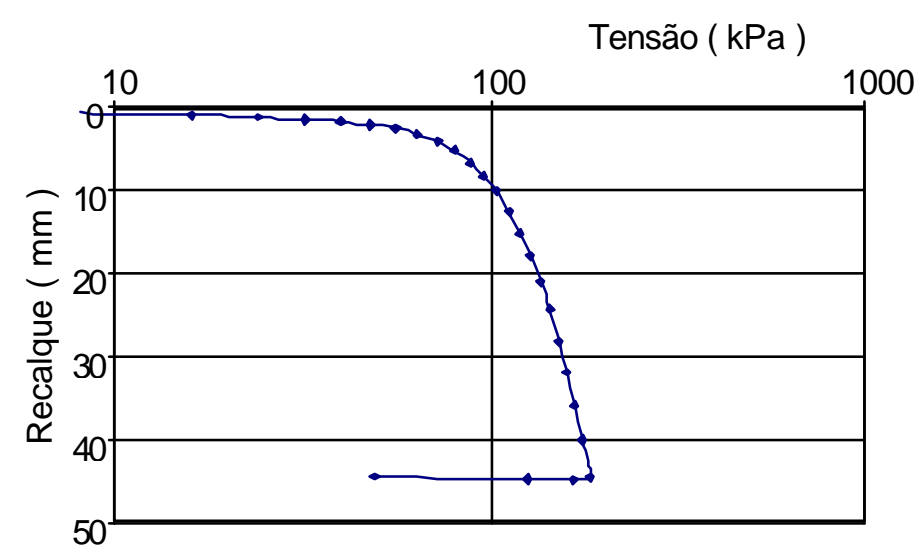

FIGURA 2.11 - Curva típica log tensão x recalque (MACACARI, 2001) 


\subsubsection{3 - CRITÉRIO D/30}

De acordo com TEIXEIRA \& GODOY (1996), na interpretação dos resultados de uma prova de carga, deverão ser atendidos sempre aos seguintes critérios de ruptura e recalques que norteiam qualquer projeto de fundação. Assim, tem-se que:

- Critério de recalque: $\sigma_{\mathrm{a}} \leq \sigma_{\mathrm{x}}$

- Critério de ruptura: $\sigma_{\mathrm{a}} \leq \sigma^{*} / \mathrm{F}$

em que:

$\sigma_{\mathrm{x}}$ é a tensão que corresponde a um recalque x considerado admissível;

$\sigma^{*}$ é a tensão que corresponderá a um dos seguintes valores:

$\sigma^{*}=\sigma_{\mathrm{f}}$ quando a ruptura for alcançada na prova de carga (caracterizada pelo aumento incessante dos recalques sob tensão aplicada constante).

$\sigma^{*}=\sigma_{\mathrm{y}}$, tensão que corresponde a um recalque $\mathrm{y}$, julgado excessivo (ruptura técnica).

$\sigma^{*}=\sigma_{\text {máx }}$, tensão máxima aplicada na prova de carga, quando não se alcança nenhum dos casos anteriores.

$\mathrm{F}=$ fator de segurança, em geral 2.

Ainda, segundo TEIXEIRA \& GODOY (1996), a seção de solos do IPT de São Paulo, responsável pela introdução no Brasil das primeiras técnicas de investigação sistemática do subsolo, executou também as primeiras provas de carga sobre placa, que foram interpretadas de acordo com os critérios do código de obras da cidade de Boston, USA, o qual estipula para placas de $0,30 \mathrm{~m}$ x $0,30 \mathrm{~m}$ :

$$
\begin{aligned}
& x=10 \mathrm{~mm} \\
& y=25 \mathrm{~mm} \\
& F=2
\end{aligned}
$$

Deste modo, tem-se: 
a) Critério de recalque: $\sigma_{\mathrm{a}} \leq \sigma_{10}$

b) Critério de ruptura: $\sigma_{\mathrm{a}} \leq \sigma_{25} / 2$

Por esse critério, são considerados dois valores de recalque (10 mm e $25 \mathrm{~mm}$ ) e as correspondentes tensões $\left(\sigma_{10}\right.$ e $\left.\sigma_{25}\right)$ na curva tensão x recalque. Então, a tensão admissível será dada pelo menor dos dois seguintes valores: $\sigma_{10} \mathrm{e}^{1 / 2} \sigma_{25}$, isto é:

$$
\sigma_{a} \leq\left\{\begin{array}{l}
\sigma_{10} \\
\frac{\sigma_{25}}{2}
\end{array}\right.
$$

Portanto, esse critério estabelece para a placa um recalque admissível $\rho_{\mathrm{a}}$ de 10 $\mathrm{mm}$ e um critério de ruptura convencional em que a tensão de ruptura $\sigma_{\mathrm{r}}$ está associada ao recalque arbitrário de $25 \mathrm{~mm}$, correspondendo o denominador 2 ao fator de segurança. De acordo com TEIXEIRA \& GODOY (1996), o valor de $1 / 2 \sigma_{25}$ é sempre mais rigoroso que $\sigma_{10}$.

O critério do código de Boston foi importado sem nenhuma adaptação para a placa circular de 0,80 m de diâmetro, padronizada pela NBR 6489/1984. Mesmo assim, mostrou-se adequado ao projeto de fundações de edifícios de grande porte construídos na cidade de São Paulo, segundo TEIXEIRA \& GODOY (1996).

Então, pode-se estabelecer o recalque de $25 \mathrm{~mm}$ como critério de ruptura convencional para interpretar os resultados de ensaios de placa com diâmetro de $0,80 \mathrm{~m}$. Para adimensionalizar esse valor de recalque, com vis ta a sua aplicação para sapatas maiores que a placa na norma brasileira, pode-se considerá-lo como equivalente a:

$$
\frac{\mathrm{D}}{30}
$$

em que D é o diâmetro da placa ou da sapata.

Por coincidência, essa relação adimensional constitui a parcela independente do encurtamento elástico no critério de ruptura convencional da NBR 6122/1996 para provas de carga em estaca:

$$
\frac{\mathrm{D}}{30}+\frac{\mathrm{PL}}{\mathrm{AE}}
$$




\section{5 - SOLOS COLAPSÍVEIS}

\subsection{1 - INTRODUÇÃO}

Segundo VILAR et al. (1981), os solos colapsíveis são encontrados em várias partes do mundo e aparecem em grande quantidade nas regiões de clima tropical. Destacam-se as condições básicas para um solo potencialmente colapsível: um alto índice de vazios e um teor de umidade menor que o necessário para completa saturação do solo.

Alguns solos, ao se aumentar o conteúdo de água em seus vazios ou ao serem carregados e posteriormente umedecidos, experimentam uma redução de volume manifestada por uma brusca variação do índice de vazios sem aumento das cargas aplicadas.

Conforme CINTRA (1998), em certos tipos de solo não-saturado, sua inundação pode causar uma espécie de colapso da sua estrutura, caracterizado por um recalque suplementar, repentino e de grandes proporções. Este tipo de recalque é chamado de “colapso" e o solo é classificado como "colapsível".

As fundações de edifícios implantadas em solo colapsíveis podem se comportar satisfatoriamente por algum tempo, mas bruscamente sofrer um recalque adicional (Figura 2.12), em geral de considerável magnitude, devido ao aparecimento acidental de uma fonte de água que passa a inundar o solo, como por exemplo: ruptura de condutos de água ou esgoto, infiltração de água de chuva, fissuras e trincas em reservatório enterrado, ascensão do lençol freático, etc. (CINTRA,1998).

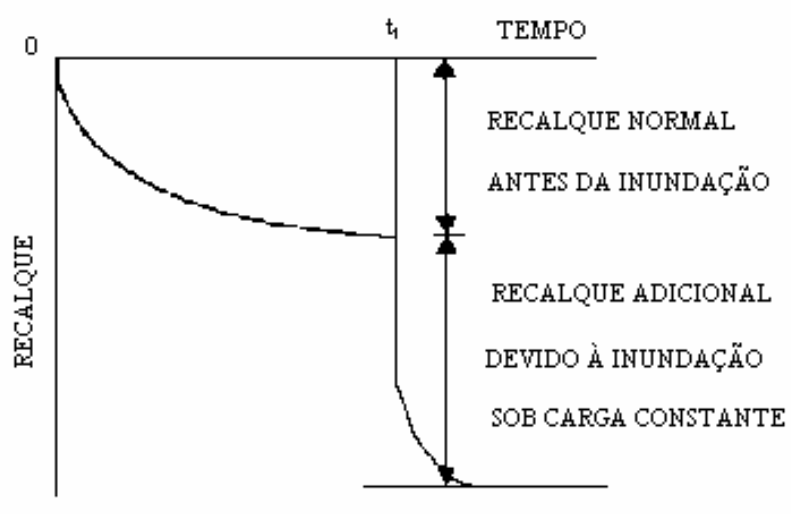

FIGURA 2.12 - Conceito básico de recalque adicional devido ao colapso da estrutura do solo (JENNINGS \& KNIGHT, 1975 apud CINTRA, 1998) 
As regiões tropicais apresentam condições flagrantes para o desenvolvimento de solos potencialmente colapsíveis, quer pela lixiviação de finos dos horizontes superficiais nas regiões onde se alternam estações de relativa seca e de precipitações intensas, quer pelos solos com deficiência de umidade que se desenvolvem em regiões áridas e semi-áridas (VILAR et al., 1981).

VILAR et al. (1981) citam que o fator estrutura é altamente determinante do comportamento e das características que os solos colapsíveis exibem. As estruturas porosas desses solos apresentam uma situação de equilíbrio meta-estável entre as partículas constituintes, as quais são mantidas em sua posição pela presença de algum vínculo capaz de conferir ao solo uma resistência temporária. Os principais fatores responsáveis por este aumento temporário da resistência do solo são as forças capilares, as forças eletromagnéticas de superfície e a presença de alguma substância cimentante, como os óxidos de ferro e os carbonatos.

Segundo CINTRA (1998), o solo colapsível apresenta uma estrutura instável, porém com uma rigidez temporária mantida pela pressão de sucção e/ou cimentação.

A fundação por sapatas é o tipo de fundação mais afetado pelo problema da colapsibilidade, pois, por se tratar de fundação eminentemente rasa, estará inevitavelmente apoiada na camada colapsível, mais superficial. Por isso, mesmo que a camada superficial seja pouco espessa, a redução da capacidade de carga por influência da inundação é tão significativa que inviabiliza o emprego de sapatas (CINTRA, 1998).

Mas CINTRA et al. (2003) relatam que uma solução que pode viabilizar o emprego de fundações por sapatas em solos colapsíveis. Trata-se da remoção da camada de apoio de cada sapata, na espessura correspondente à largura da sapata, e sua reposição em subcamadas compactadas, conforme esquema da Figura 2.13.

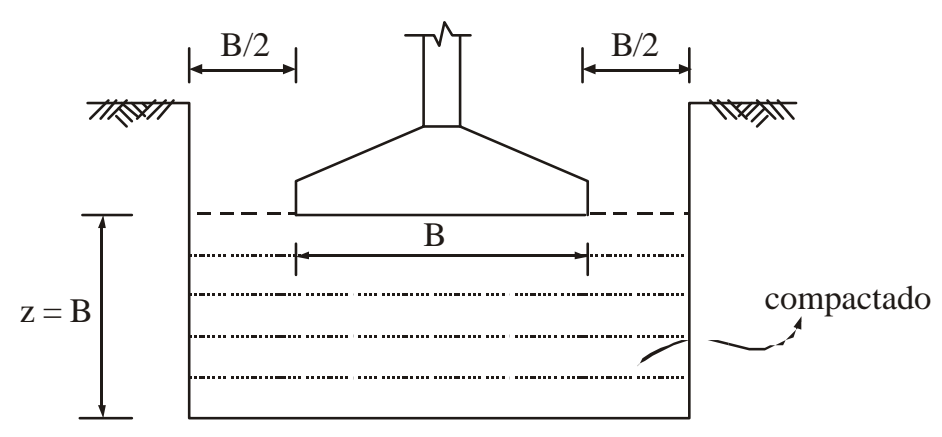

FIGURA 2.13 - Uso de sapatas em solo colapsível compactado (CINTRA et al., 2003) 
Às vezes, a manifestação do colapso pode se tornar um problema social, como foi o caso, por exemplo, das intensas chuvas que ocorreram no interior do Estado de São Paulo, em 1995. A Defesa Civil constatou algum tipo de dano em cerca de 4.000 edificações, na cidade de Araraquara, SP, onde se registrou a precipitação de $135 \mathrm{~mm}$ no dia 31/1 e de $660 \mathrm{~mm}$ em dez dias de chuvas ininterruptas. Em tubulões escavados, mas ainda não concretados, constatou-se a elevação de $4 \mathrm{~m}$ no nível d'água, o que perdurou por mais de um mês (CINTRA, 1998).

É o caso também de inúmeros conjuntos habitacionais populares que são construídos em terrenos colapsíveis, sem qualquer medida preventiva ao colapso, A ocorrência de trincas e fissuras generalizadas em épocas de chuva, em consequiência do colapso do solo, exige reparações muitas vezes incompatíveis com o baixo custo dessas moradias; além disso, essas reparações geralmente precisam ser repetidas após cada novo período anual de chuvas (CINTRA, 1998).

Para um solo colapsível entrar efetivamente em colapso, duas condições básicas devem ser satisfeitas: a elevação do teor de umidade até um certo valor limite e a atuação de um estado de tensões crítico (ou limite inferior) que, em fundações, é representado pela carga de colapso, segundo terminologia adotada por CINTRA (1998). Assim, se a carga atuante é suficientemente elevada, a adição de água ao solo colapsível produz um efeito adverso ou destrutivo, pois reduz ou dissipa a sucção e/ou enfraquece e até destrói a cimentação, causando a redução da resistência e, portanto, o colapso do solo.

Segundo CINTRA (1998), o colapso provoca uma descontinuidade na curva tensão x deformação, conforme ilustrado pela Figura 2.14, a qual representa uma prova de carga com inundação do solo durante o ensaio. 


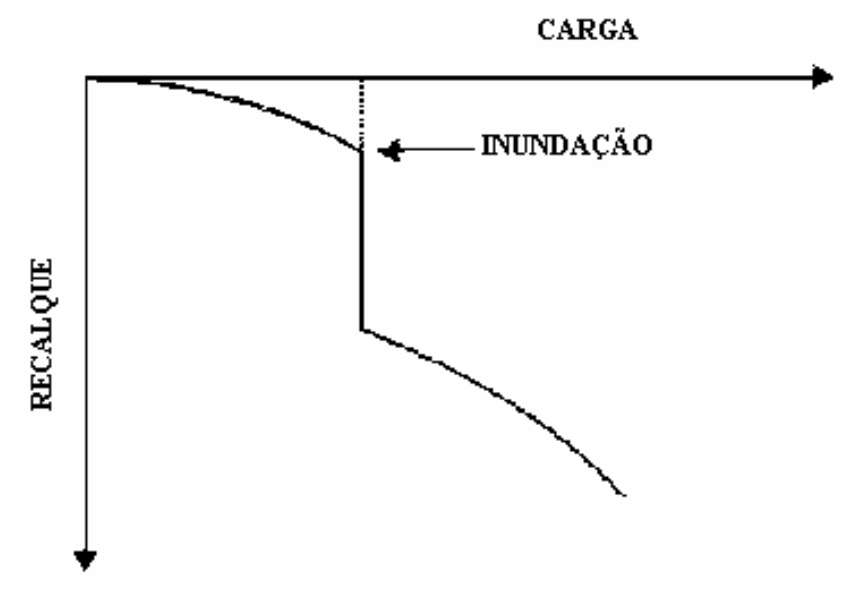

FIGURA 2.14 - Ocorrência de colapso em prova de carga realizada com inundação do solo durante o ensaio (CINTRA, 1998)

À conceituação tradicional de colapso sob carga constante, passourse a acrescentar, ultimamente, o caso em que a inundação precede ao início do carregamento. Nesse caso de inundação prévia, a colapsibilidade se manifesta não por um recalque abrupto, pois não há descontinuidade da curva tensão x deformação, mas pelo aumento da deformabilidade e conseqüente redução da capacidade de carga, conforme ilustrado pela Figura 2.15 (CINTRA, 1998).

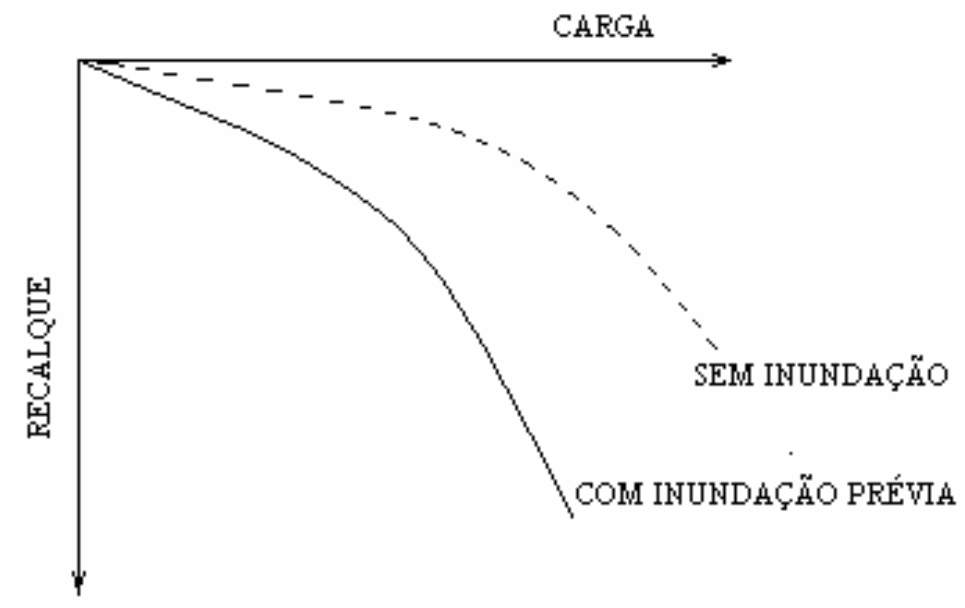

FIGURA 2.15 - Prova de carga em solo colapsível previamente inundado (CINTRA, 1998) 


\subsection{2 - INFLUÊNCIA DA SUCÇÃO}

CINTRA et al. (2003) citam que os solos colapsíveis, em condições de baixo teor de umidade, apresentam uma espécie de "resistência aparente" graças à pressão de sucção que se desenvolve em seus vazios. Por isso, em termos de fundações, quanto mais seco o solo colapsível, maior a sucção e, consequentemente, maior a capacidade de carga. Ao contrário, quanto mais úmido, menor a sucção e, em conseqüência, menor a capacidade de carga, até o extremo do solo inundado, ou sucção nula, em que a capacidade de carga atinge o seu valor mínimo.

Esse importante papel da sucção na capacidade de carga foi demonstrado teoricamente por FREDLUND \& RAHARDJO (1993). Esses autores correlacionaram a sucção com a capacidade de carga utilizando a equação de TERZAGHI (1943), demonstrando a influência da sucção matricial na capacidade de carga de um maciço de solo sob sapatas corridas de 0,5 e $1 \mathrm{~m}$ de largura a 0,5 $\mathrm{m}$ de profundidade (Figura 2.16).

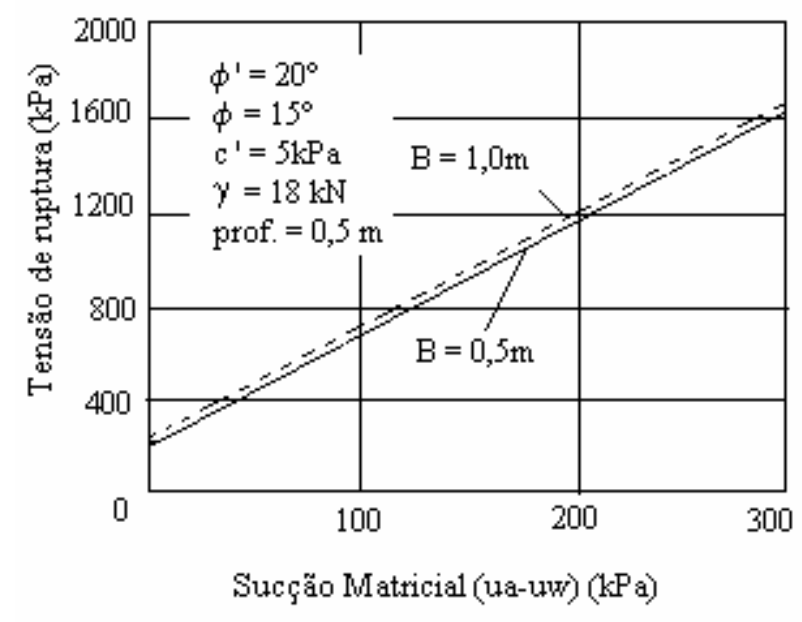

FIGURA 2.16 - Variação da tensão de ruptura de sapatas corridas em função da sucção matricial (FREDLUND \& RAHARDJO, 1993)

Experimentalmente foi COSTA (1999) que comprovou que a sucção matricial possui grande influência na capacidade de carga. Por meio de provas de carga em placa de 0,80 m de diâmetro, a 1,5 $\mathrm{m}$ de profundidade, esse autor comprovou que um pequeno aumento na sucção causa um substancial crescimento da capacidade de carga, como pode ser observado na Figura 2.17. 


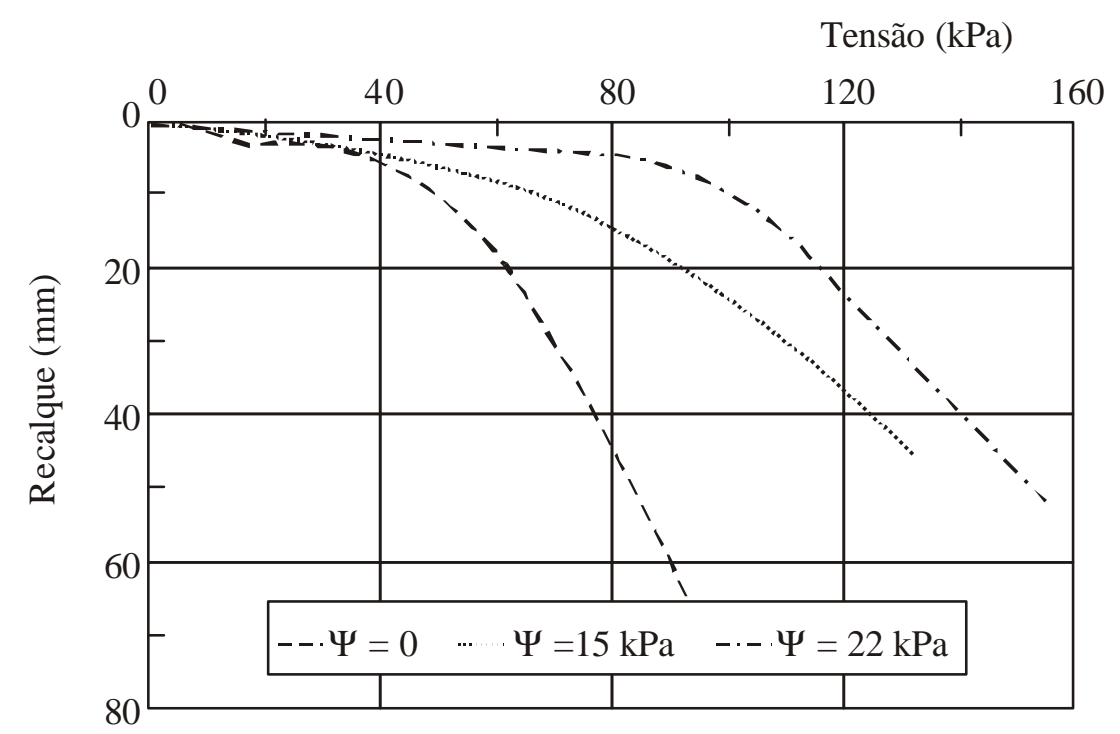

FIGURA 2.17 - Curvas tensão x recalque de provas de carga sobre placa em solo não-saturado com diferentes sucções (COSTA, 1999)

Em continuidade à pesquisa de COSTA (1999), MACACARI (2001) realizou provas de carga em placa de 0,80 $\mathrm{m}$ de diâmetro, em diferentes profundidades, quantificando a influência da sucção e da profundidade da placa na capacidade de carga, conforme a Figura 2.18.

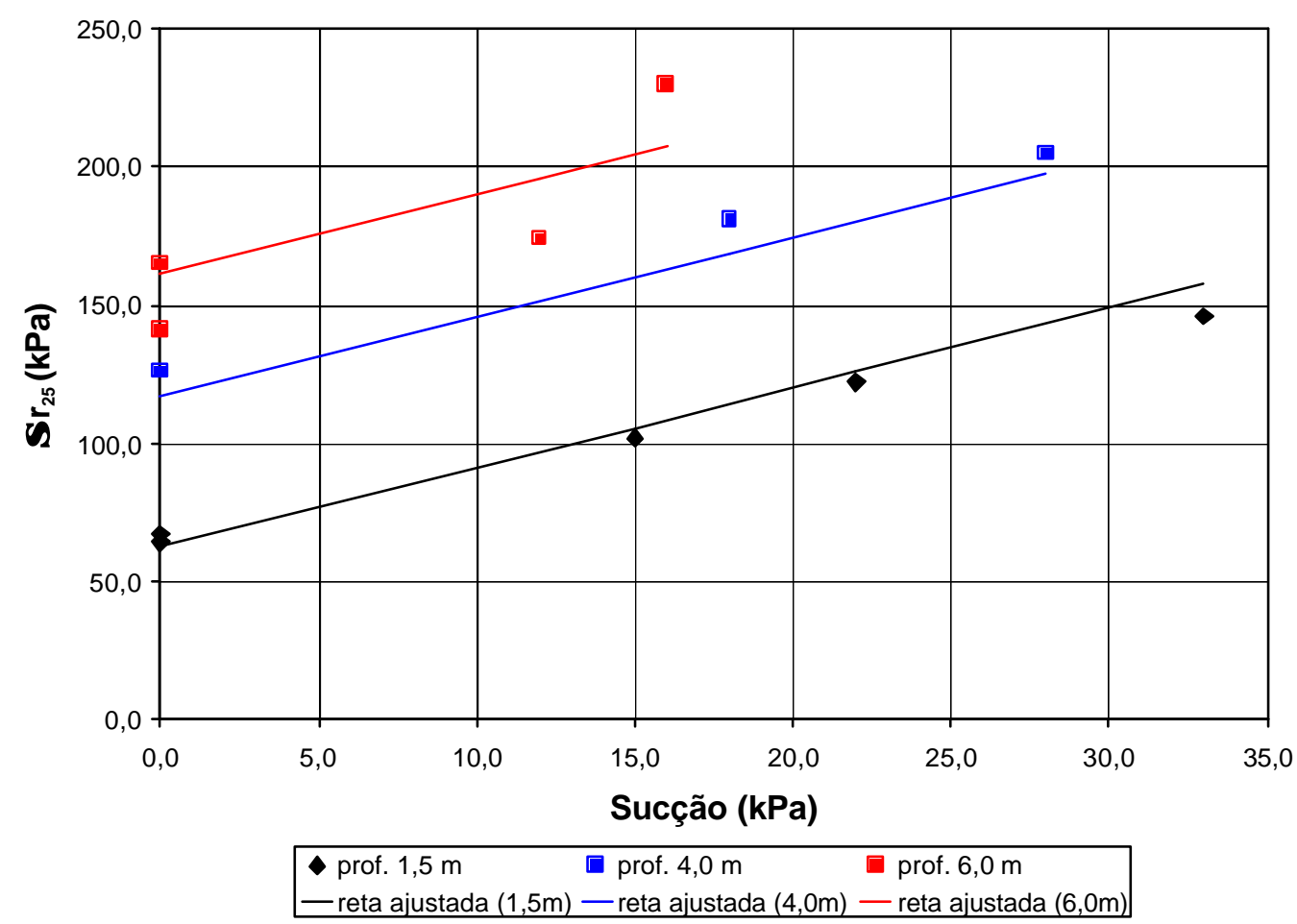

FIGURA 2.18 - Influência da sucção e da profundidade na capacidade de carga (MACACARI, 2001) 


\section{MATERIAIS E MÉTODOS}

\section{1 - INTRODUÇÃO}

Neste item, estão descritos o Campo Experimental de Fundações da USP de São Carlos, onde foram executados os ensaios penetrométricos, o equipamento utilizado, e os procedimentos de ensaio adotados.

\section{2 - CAMPO EXPERIMENTAL}

\subsection{1 - Características Geológicas}

No Campo Experimental de Fundações da USP de São Carlos, a camada superficial de 6,0 m de espessura, comprovadamente colapsível, é composta por areia argilosa marrom escura (Sedimento Cenozóico) com valores de $\mathrm{N}_{\mathrm{SPT}}$ da ordem de 1 a 5 golpes. A partir dessa profundidade, separada por uma linha de seixos de aproximadamente $0,20 \mathrm{~m}$ de espessura, há uma camada formada por areia argilosa de cor variegada (Solo Residual do Grupo Bauru). O nível d'água se encontra variando de - 8,0 m a -10,0 m, em função da época de realização das sondagens.

A Figura 3.1 apresenta o perfil geotécnico obtido em sondagens realizadas no Campo Experimental de Fundações, bem como os valores mínimos, médios e máximos de $\mathrm{N}_{\mathrm{SPT}}$, além do coeficiente de variação, em função da profundidade. 


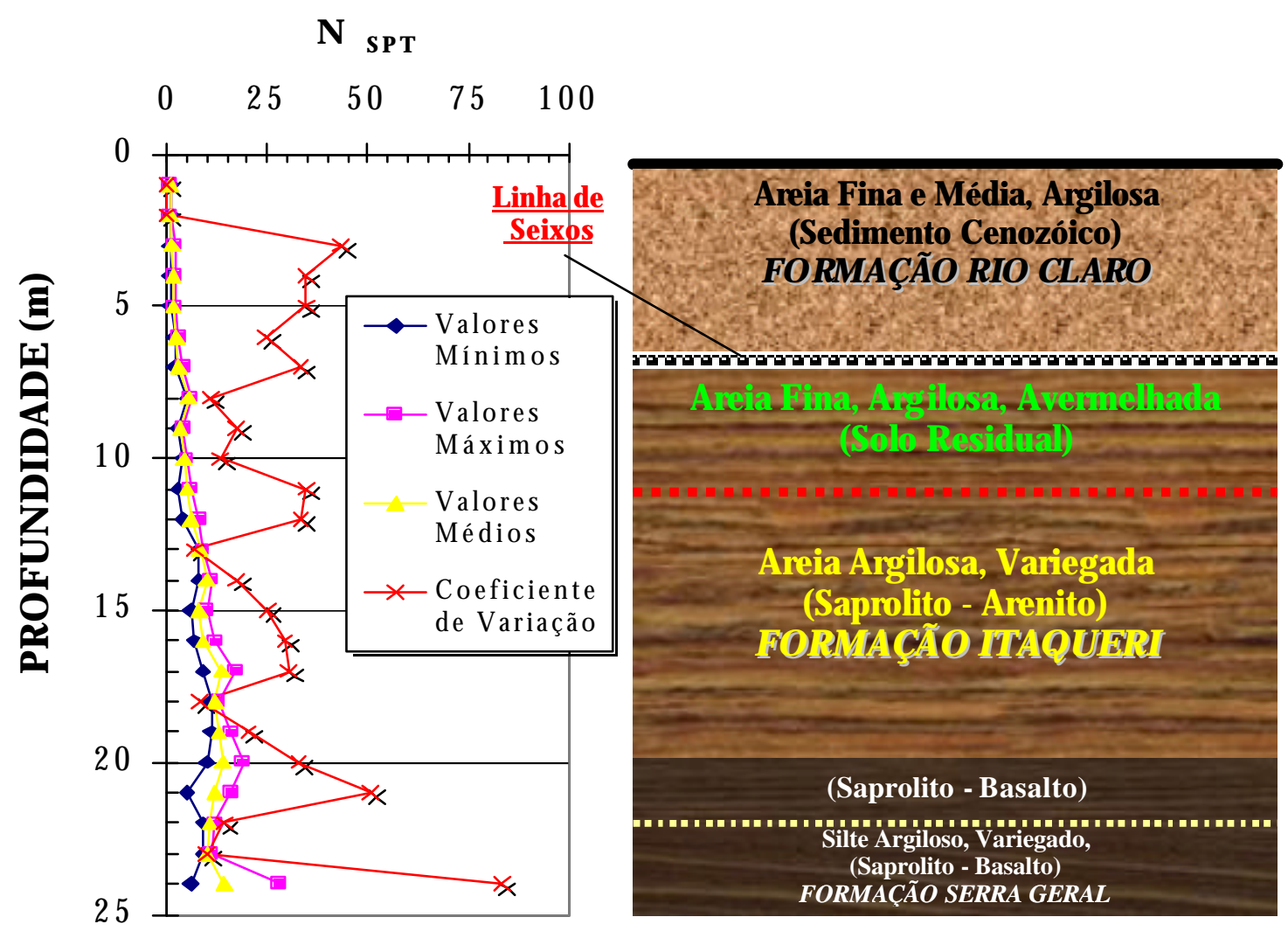

FIGURA 3.1 - Perfil geotécnico representativo do Campo Experimental (AOKI, 2000)

Segundo AOKI (2000), o maciço de solos em questão apresenta quatro unidades de formação geológica:

- Formação Rio Claro, constituída por areia fina e média, argilosa pouco compacta e muito porosa, possuindo uma característica um pouco mais homogênea (coeficiente de variação entre 20 e $25 \%$ ). Tal variabilidade é função da própria variação da pressão de sucção com a profundidade, já que esta camada encontra-se acima do nível d'água.

- Formação Itaqueri, encontrada abaixo da linha de seixos e dividida em duas subcamadas: uma de solo residual, apresentando pouca variação (em torno de $25 \%$, e constante com a profundidade) e outra de um saprolito de arenito que possui características bem mais heterogêneas, principalmente, devido ao grau de alteração da rocha, gerando assim uma grande variabilidade.

- Formação Serra Geral, encontrada na porção inferior, no contato com uma alteração de basalto. Possui uma certa importância já que ainda pode ser perfurada e amostrada em certos pontos em função do manto de intemperismo existente e da sua própria geometria. 
- Formação Botucatu, localizada abaixo da Formação Serra Geral, não podendo ser perfurada por sondagem à percussão.

\subsection{2 - Locação dos Ensaios}

Os ensaios com penetrômetro foram realizados em nove cavas, à profundidade de 1,50 m, com diâmetros de $0,50 \mathrm{~m}$ a $1,70 \mathrm{~m}$, de acordo com o esquema de locação da Figura 3.2. Essas mesmas cavas foram utilizadas para ensaios de placa de diferentes diâmetros por VIANNA \& CINTRA (2003).

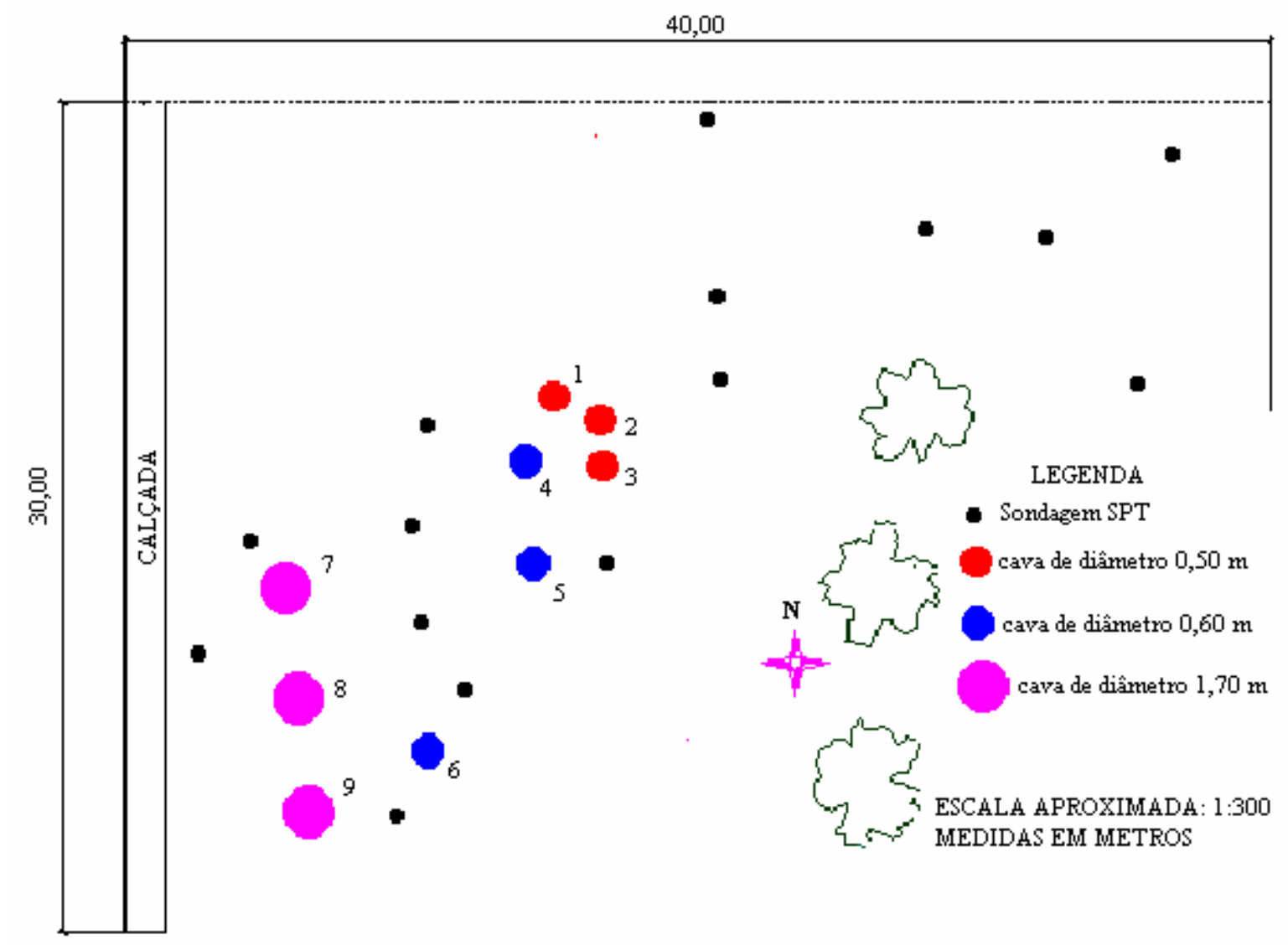

FIGURA 3.2 -Esquema de locação das cavas ensaiadas com penetrômetro 


\section{3 - EQUIPAMENTO}

\subsection{1 - Equipamento Utilizado}

Para a realização dos ensaios, foi utilizado um penetrômetro de solos da marca Solotest - ref.1.210.001, mostrado na Figura 3.3.

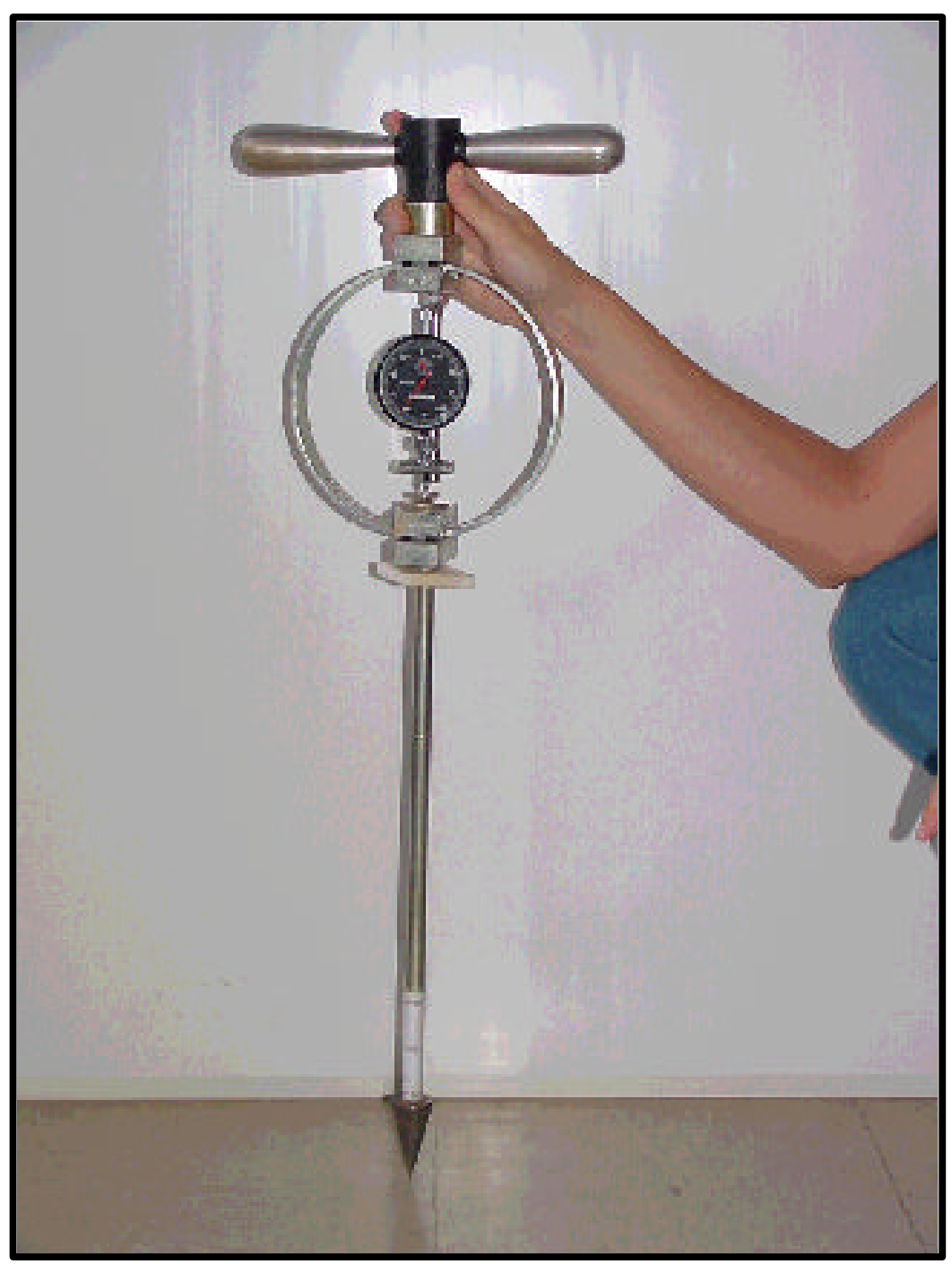

FIGURA 3.3 - Penetrômetro de solos - marca Solotest - ref. 1.210.001

O equipamento é composto de maçaneta dupla (guidão), 1 haste de $381 \mathrm{~mm}$, um anel dinamométrico com capacidade de $1 \mathrm{kN}$ (Figura 3.4), uma ponta cônica removível com 28,4 mm de diâmetro e $55 \mathrm{~mm}$ de altura. O relógio comparador do anel possui uma trava para possibilitar o operador fazer uma leitura mais precisa (após a leitura aperta-se 
o botão abaixo do mostrador para o ponteiro voltar ao zero inicial, pois sempre ficará registrada no relógio a maior leitura de resistência medida).

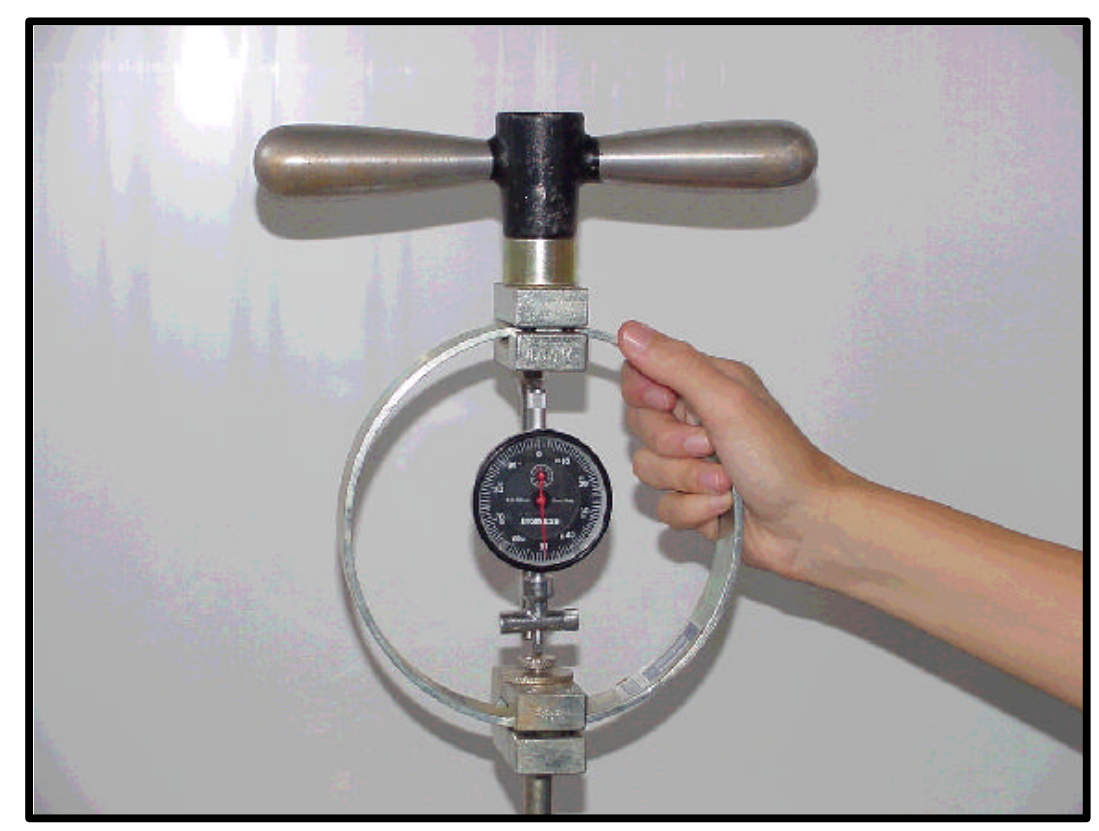

FIGURA 3.4 - Anel dinamométrico com capacidade de $1 \mathrm{kN}$

Após a montagem, deve-se verificar se as luvas de conexão estão bem acopladas e se o relógio comparador está seguro. Em seguida o aparelho é posicionado na vertical em relação ao local de ensaio e o relógio comparador é zerado.

\subsubsection{Adaptações}

Foram feitas algumas adaptações no penetrômetro da Solotest para se obter "medidas de resistência x penetração" do conjunto haste/ponta, como está descrito a seguir:

- Adaptação 1 (Figura 3.5) - foi colada na haste uma régua plastificada impermeável para controlar a penetração do conjunto haste/ponta, para leituras de penetração de 6,9 e $12 \mathrm{~cm}$. 


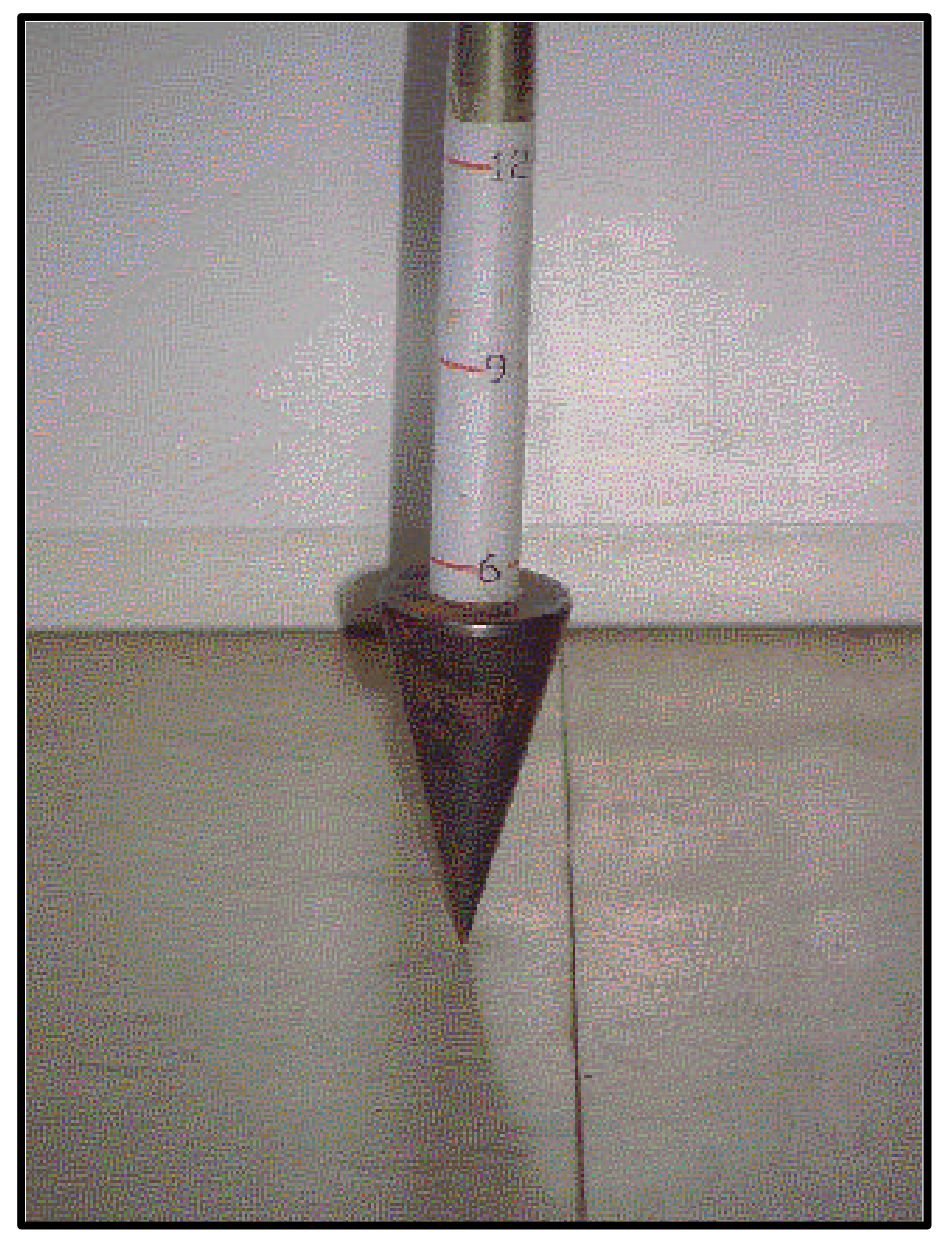

FIGURA 3.5 - Régua da haste do penetrômetro

- Adaptação 2 (Figura 3.6) - foi colocada na haste uma placa de borracha que desliza com certo atrito, permitindo indicar na haste a penetração desejada. Essa adaptação facilita a decisão do operador de interromper a penetração do conjunto haste/ponta, possibilitando assim, um ensaio mais preciso. 


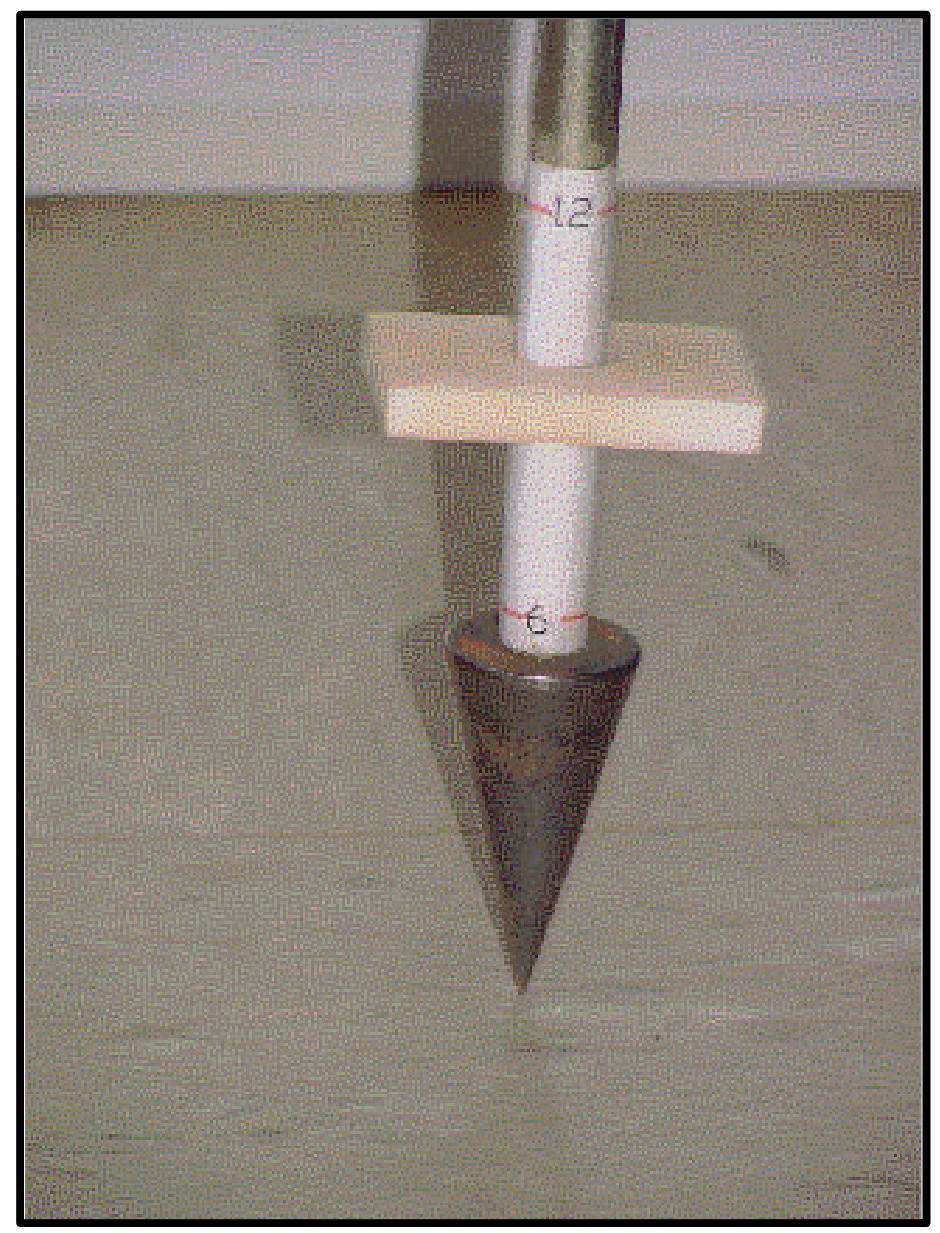

FIGURA 3.6 - Placa de borracha do penetrômetro

\subsection{Procedimentos de ensaio}

\subsubsection{Monitoração da Sucção}

Anteriormente aos ensaios penetrométricos, foram instalados tensiômetros (Figura 3.7) nas cavas, para medir os valores de sucção do solo no momento do ensaio. O valor de sucção foi determinado pela média das leituras em quatro tensiômetros por cava, e após este procedimento, foram feitas as leituras com o penetrômetro. Para cada tamanho de cava, foi feito um ensaio inundado, ou seja, com sucção praticamente nula. 


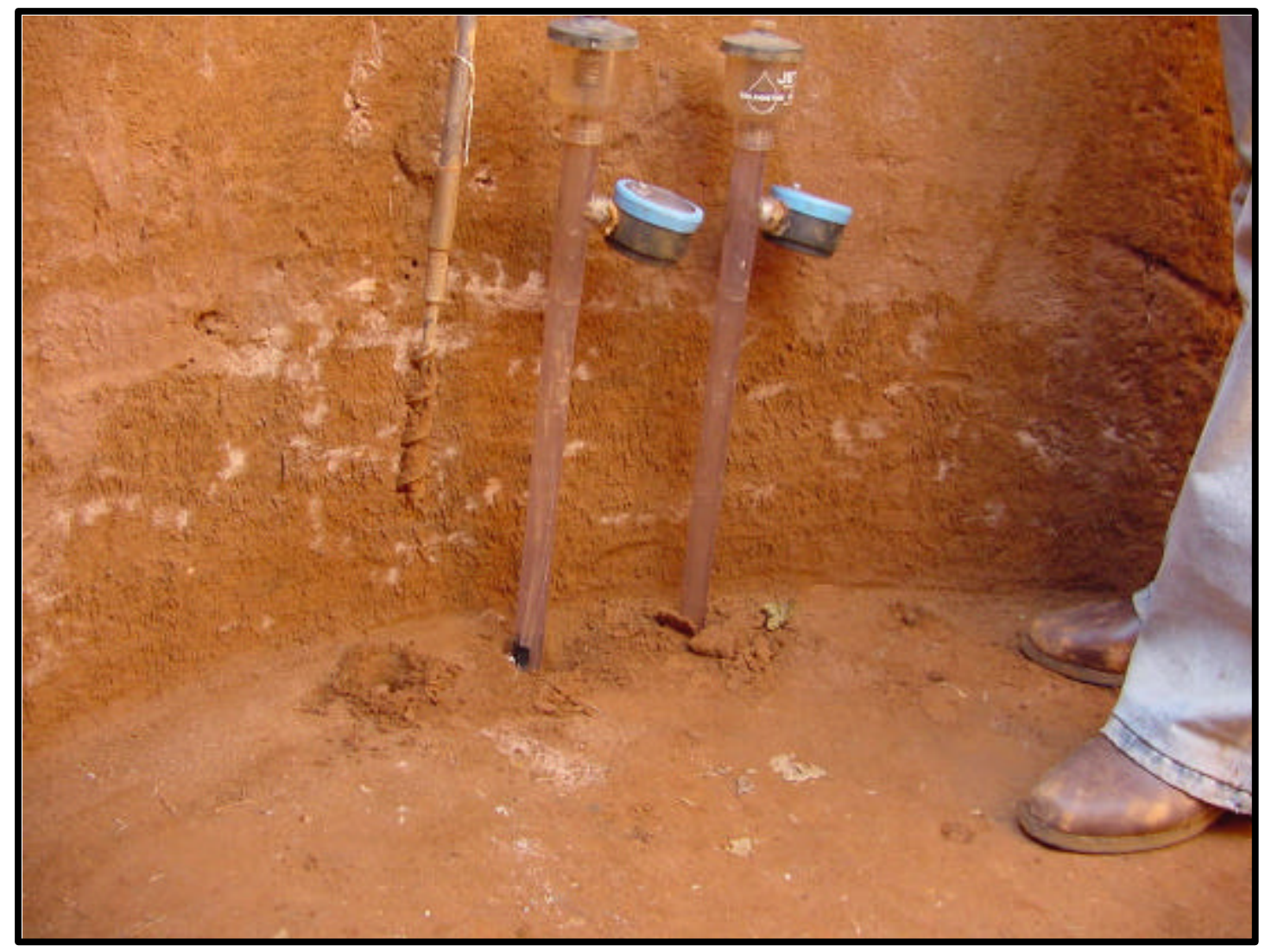

FIGURA 3.7 - Instalação de tensiômetros no local do ensaio para monitoração da sucção do solo

\subsubsection{Ensaio Penetrométrico}

Para determinar o número mínimo de pontos a serem ensaiados por cava, de modo que fosse obtida uma boa representação da resistência do solo à penetração do penetrômetro, foram executados testes iniciais. Realizaram-se penetrações de $10 \mathrm{~cm}$ do penetrômetro no solo, em 15 pontos distintos e eqüidistantes entre si, em uma cava de 1,70 m de diâmetro, à profundidade de 1,50 m, cujos valores são apresentados na Tabela 1. 
TABELA 1 - Resistência à penetração de $10 \mathrm{~cm}$ do penetrômetro na cava teste $(\mathrm{R}, \mathrm{em}$ $\mathrm{kN})$

\begin{tabular}{|c|c|c|c|c|c|c|c|c|c|c|c|c|c|c|c|}
\hline leitura & $\mathrm{R}(\mathrm{kN})$ & $\mathrm{R}(\mathrm{kN})$ & $R(k N)$ & $R(\mathrm{kN})$ & $\mathrm{R}(\mathrm{kN})$ & $\mathrm{R}(\mathrm{kN})$ & $R(\mathrm{kN})$ & $\mathrm{R}(\mathrm{kN})$ & $\mathrm{R}(\mathrm{kN})$ & $\mathrm{R}(\mathrm{kN})$ & $R(k N)$ & $\mathrm{R}(\mathrm{kN})$ & $\mathrm{R}(\mathrm{kN})$ & $\mathrm{R}(\mathrm{kN})$ & $\mathrm{R}(\mathrm{k}$ \\
\hline 1 & 0,53 & 0,53 & 0,53 & 0,53 & 0,53 & 0,53 & \begin{tabular}{|l|}
0,53 \\
\end{tabular} & 0,53 & 0,53 & 0,53 & 0,53 & 0,53 & 0,53 & 0,53 & 0,53 \\
\hline 2 & 0,49 & 0,49 & 0,49 & 0,49 & 0,49 & 0,49 & \begin{tabular}{|l|}
0,49 \\
\end{tabular} & 0,49 & 0,49 & 0,49 & \begin{tabular}{|l|}
0,49 \\
\end{tabular} & 0,49 & 0,49 & 0,49 & 0,49 \\
\hline 3 & 0,47 & & 0,48 & 0,48 & 0,48 & 0,48 & \begin{tabular}{|l|}
0,48 \\
\end{tabular} & 0,48 & 0,48 & 0,48 & \begin{tabular}{|l|}
0,48 \\
\end{tabular} & \begin{tabular}{|l|}
0,48 \\
\end{tabular} & 0,48 & 0,48 & 0,48 \\
\hline 4 & 0.49 & & & 0.49 & 0.49 & 0.49 & 0.49 & 0.49 & 0.49 & 0.49 & \begin{tabular}{|l|}
0.49 \\
\end{tabular} & 0.49 & 0.49 & 0.49 & 0.49 \\
\hline$\tau$ & 0,49 & & & & 0,49 & 0,49 & \begin{tabular}{|l|}
0,49 \\
\end{tabular} & 0,49 & 0,49 & 0,49 & \begin{tabular}{|l|}
0,49 \\
\end{tabular} & 0,49 & 0,49 & 0,49 & 0,49 \\
\hline 6 & 0,46 & & & & & 0,46 & \begin{tabular}{|l|}
0,46 \\
\end{tabular} & 0,46 & 0,46 & 0,46 & \begin{tabular}{|l|}
0,46 \\
\end{tabular} & 0,46 & 0,46 & 0,46 & 0,46 \\
\hline 7 & 0.49 & & & & & & 0.49 & 0.49 & 0.49 & 0.49 & \begin{tabular}{|l|}
0.49 \\
\end{tabular} & 0.49 & 0.49 & 0.49 & \begin{tabular}{|l|}
0.49 \\
\end{tabular} \\
\hline 8 & 0,51 & & & & & & & 0,51 & 0,51 & \begin{tabular}{|l|}
0,51 \\
\end{tabular} & \begin{tabular}{|l|}
0,51 \\
\end{tabular} & \begin{tabular}{|l|}
0,51 \\
\end{tabular} & 0,51 & 0,51 & 0,51 \\
\hline 9 & 0,56 & & & & & & & & 0,56 & 0,56 & 0,56 & 0,56 & 0,56 & 0,56 & 0,56 \\
\hline 10 & 0.50 & & & & & & & & & 0.50 & \begin{tabular}{|l|}
0.50 \\
\end{tabular} & 0.50 & 0.50 & 0.50 & \begin{tabular}{|l|}
0.50 \\
\end{tabular} \\
\hline 11 & 0.56 & & & & & & & & & & 0,56 & 0,56 & 0.56 & 0.56 & \begin{tabular}{|l|}
0.56 \\
\end{tabular} \\
\hline 12 & 0,54 & & & & & & & & & & & 0,54 & \begin{tabular}{|l|}
0,54 \\
\end{tabular} & 0,54 & \begin{tabular}{|l|}
0,54 \\
\end{tabular} \\
\hline 13 & 0,56 & & & & & & & & & & & & \begin{tabular}{|l|}
0,56 \\
\end{tabular} & 0,56 & \begin{tabular}{|l|}
0,56 \\
\end{tabular} \\
\hline 14 & 0.53 & & & & & & & & & & & & & 0.53 & \begin{tabular}{|l|}
0.53 \\
\end{tabular} \\
\hline 15 & 0,49 & & & & & & & & & & & & & & 0,49 \\
\hline média & 0.51 & 0.51 & 0.50 & 0.50 & 0.50 & 0.49 & 0.49 & 0.49 & 0.50 & 0.50 & 0.51 & 0.51 & 0.51 & 0.51 & 0.51 \\
\hline desvio padrão & 0,03 & 0,03 & 0,03 & 0,02 & 0,02 & 0,02 & 0,02 & 0,02 & 0,03 & \begin{tabular}{|l|}
0,03 \\
\end{tabular} & \begin{tabular}{|l|}
0,03 \\
\end{tabular} & 0,03 & 0,03 & 0,03 & 0,03 \\
\hline cV & 0,06 & 0,05 & 0,05 & 0,04 & 0,04 & 0,05 & \begin{tabular}{|l|}
0,04 \\
\end{tabular} & 0,04 & 0,06 & 0,05 & \begin{tabular}{|l|}
0,06 \\
\end{tabular} & 0,06 & 0,06 & 0,06 & 0,06 \\
\hline
\end{tabular}

Por meio de análise estatística, observando-se o coeficiente de variação (cv) dos valores de resistências medidos, concluiu-se que quatro ensaios por cava seria o número suficiente para garantir uma boa representatividade do local de ensaio.

$\mathrm{Na}$ fase dos ensaios, foram feitas leituras com o penetrômetro para as profundidades de penetração de 6,9 e $12 \mathrm{~cm}$, continuamente, ou seja, sem tirar o penetrômetro do solo.

Os pontos de ensaio do penetrômetro nas cavas foram locados de acordo com a Figura 3.8. Apenas nas três cavas maiores, de $1,70 \mathrm{~m}$ de diâmetro, aumentou-se para nove os pontos de ensaio, devido a maior disponibilidade de espaço e até para comprovar a validade do número mínimo de quatro. 


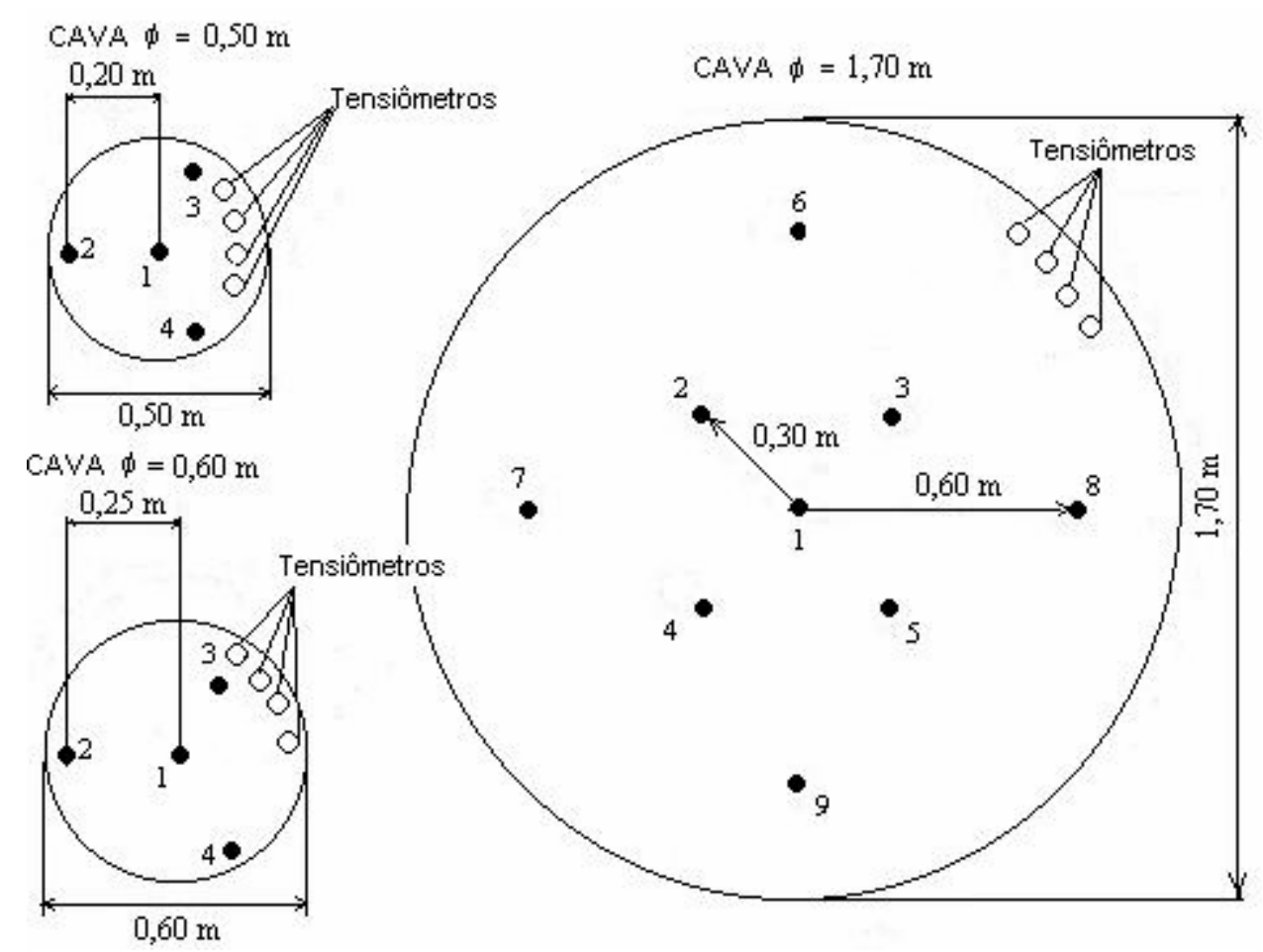

FIGURA 3.8 - Locação dos pontos de ensaio do penetrômetro no interior de cada cava

O ensaio penetrométrico não apresenta dificuldade em sua execução. $O$ equipamento é leve e fácil de ser operado. Cada ponto do ensaio nas cavas de 1,70 m de diâmetro, não levou mais do que um minuto para ser executado. Porém, nas cavas de 0,50 e 0,60 m de diâmetro, houve certa dificuldade de manuseio, devido ao pequeno espaço para o operador curvar-se no momento de deslizar a placa de borracha na haste para marcar a profundidade a ser penetrada e também para ler o resultado no mostrador do anel dinamométrico.

As Figuras 3.9 e 3.10 ilustram a realização do ensaio com o penetrômetro. 


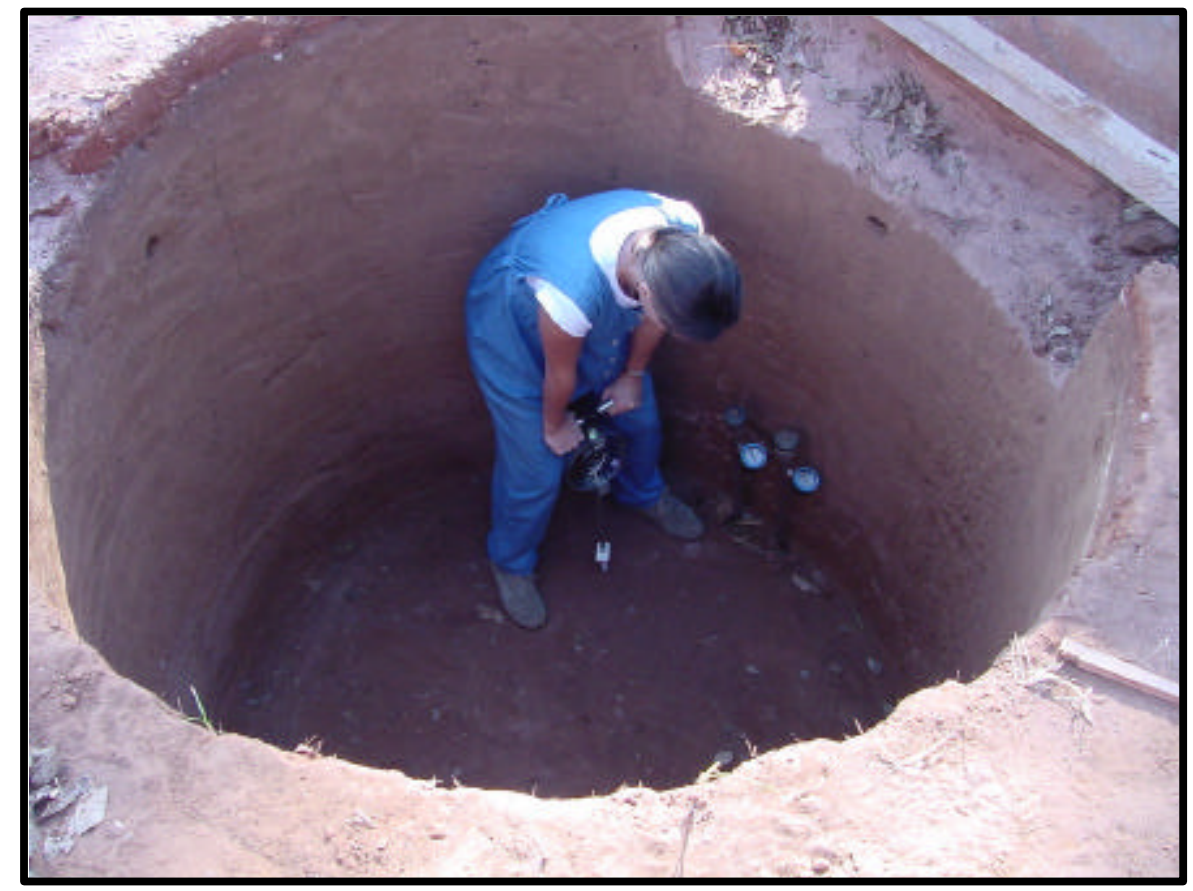

FIGURA 3.9 - Realização do ensaio com o penetrômetro (1)

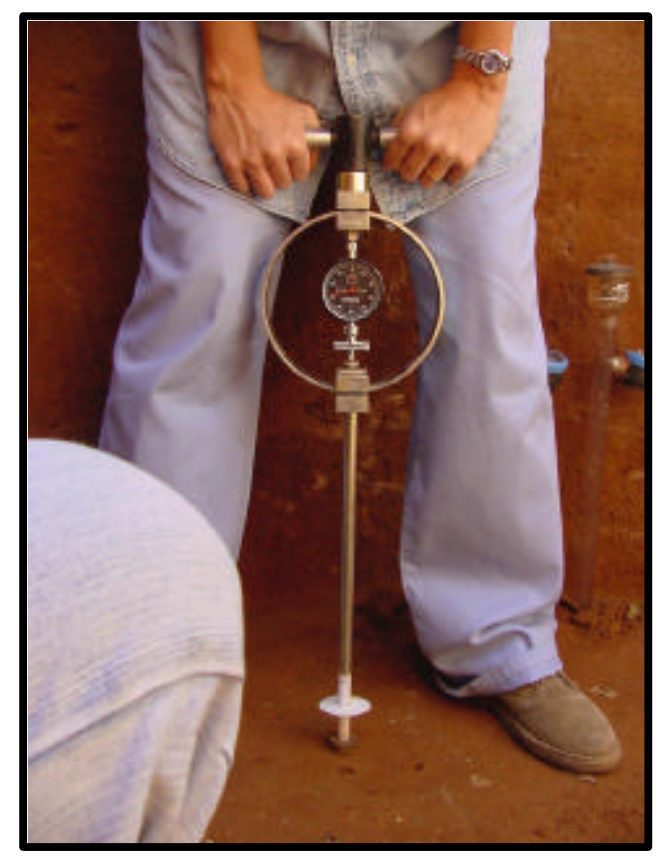

FIGURA 3.10 - Realização do ensaio com o penetrômetro (2) 
CAPÍTULO 04

\section{RESULTADOS OBTIDOS E ANÁLISE}

\section{1 - INTRODUÇÃO}

Este Capítulo apresenta os resultados obtidos nos ensaios penetrométricos realizados no Campo Experimental de Fundações da USP de São Carlos, com monitoração da sucção do solo. Esses resultados permitem avaliar a influência da sucção na resistência do solo à penetração do penetrômetro.

Em seguida, pode-se estabelecer a relação entre a tensão de ruptura obtida no ensaio penetrométrico e a capacidade de carga determinada em prova de carga em placa e em sapata, para o mesmo nível de sucção do solo.

Completando o estudo, é realizada uma comparação entre resultados de provas de carga em placas e em sapatas. 


\section{2 - RESULTADOS}

Na Tabela 2 é apresentado o valor médio da sucção obtida em cada cava, na data de ensaio do penetrômetro.

TABELA 2 - Sucção média em cada cava na data de ensaio

\begin{tabular}{|c|c|c|c|c|c|c|c|c|c|}
\hline cava & $\mathbf{1}$ & $\mathbf{2}$ & $\mathbf{3}$ & $\mathbf{4}$ & $\mathbf{5}$ & $\mathbf{6}$ & $\mathbf{7}$ & $\mathbf{8}$ & $\mathbf{9}$ \\
\hline diâmetro $(\mathbf{m})$ & 0,50 & 0,50 & 0,50 & 0,60 & 0,60 & 0,60 & 1,70 & 1,70 & 1,70 \\
\hline sucção $(\mathbf{k P a})$ & 15 & 18 & 0 & 12 & 13 & 0 & 21 & 0 & 23 \\
\hline data & $22 / 05 / 02$ & $18 / 06 / 02$ & $27 / 05 / 02$ & $13 / 05 / 02$ & $11 / 06 / 02$ & $25 / 06 / 02$ & $02 / 07 / 02$ & $06 / 08 / 02$ & $30 / 07 / 02$ \\
\hline
\end{tabular}

Nas Tabelas 3 a 5, estão exibidos os valores de resistência do solo à penetração do penetrômetro R (em $\mathrm{kPa}$ ), nas profundidades de 6, 9 e $12 \mathrm{~cm}$, locados de acordo com a Figura 3.8.

TABELA 3 - Valores de resistência do solo à penetração do penetrômetro (R, em kPa) em cavas de $0,50 \mathrm{~m}$

\begin{tabular}{|c|c|c|c|c|c|c|c|c|c|}
\hline cava & \multicolumn{4}{|c|}{$\mathbf{1}$} & \multicolumn{3}{c|}{$\mathbf{2}$} & \multicolumn{3}{c|}{3} \\
\hline penetração & $6 \mathrm{~cm}$ & $9 \mathrm{~cm}$ & $12 \mathrm{~cm}$ & $6 \mathrm{~cm}$ & $9 \mathrm{~cm}$ & $12 \mathrm{~cm}$ & $6 \mathrm{~cm}$ & $9 \mathrm{~cm}$ & $12 \mathrm{~cm}$ \\
\hline leitura & $\mathrm{R}(\mathrm{kPa})$ & $\mathrm{R}(\mathrm{kPa})$ & $\mathrm{R}(\mathrm{kPa})$ & $\mathrm{R}(\mathrm{kPa})$ & $\mathrm{R}(\mathrm{kPa})$ & $\mathrm{R}(\mathrm{kPa})$ & $\mathrm{R}(\mathrm{kPa})$ & $\mathrm{R}(\mathrm{kPa})$ & $\mathrm{R}(\mathrm{kPa})$ \\
\hline $\mathbf{1}$ (meio) & 839 & 1020 & 1025 & 898 & 914 & 914 & 328 & 413 & 482 \\
\hline $\mathbf{2}$ (canto) & 746 & 839 & 839 & 803 & 970 & 975 & 281 & 424 & 498 \\
\hline $\mathbf{3}$ (canto) & 922 & 994 & 994 & 772 & 772 & 798 & 371 & 488 & 525 \\
\hline $\mathbf{4}$ (canto) & 870 & 958 & 958 & 745 & 818 & 824 & 445 & 519 & 519 \\
\hline média & 844 & 953 & 954 & 805 & 869 & 878 & 356 & 461 & 506 \\
\hline desvio padrão & 74 & 80 & 81 & 67 & 90 & 82 & 70 & 51 & 20 \\
\hline $\begin{array}{c}\text { coeficiente } \\
\text { de variação }\end{array}$ & 0,09 & 0,08 & 0,09 & 0,08 & 0,10 & 0,09 & 0,20 & 0,11 & 0,04 \\
\hline
\end{tabular}


TABELA 4 - Valores de resistência do solo à penetração do penetrômetro (R, em kPa) em cavas de $0,60 \mathrm{~m}$

\begin{tabular}{|c|c|c|c|c|c|c|c|c|c|}
\hline cava & \multicolumn{3}{|c|}{4} & \multicolumn{3}{c|}{5} & \multicolumn{3}{c|}{ 6 } \\
\hline penetração & $6 \mathrm{~cm}$ & $9 \mathrm{~cm}$ & $12 \mathrm{~cm}$ & $6 \mathrm{~cm}$ & $9 \mathrm{~cm}$ & $12 \mathrm{~cm}$ & $6 \mathrm{~cm}$ & $9 \mathrm{~cm}$ & $12 \mathrm{~cm}$ \\
\hline leitura & $\mathrm{R}(\mathrm{kPa})$ & $\mathrm{R}(\mathrm{kPa})$ & $\mathrm{R}(\mathrm{kPa})$ & $\mathrm{R}(\mathrm{kPa})$ & $\mathrm{R}(\mathrm{kPa})$ & $\mathrm{R}(\mathrm{kPa})$ & $\mathrm{R}(\mathrm{kPa})$ & $\mathrm{R}(\mathrm{kPa})$ & $\mathrm{R}(\mathrm{kPa})$ \\
\hline $\mathbf{1}$ (meio) & 792 & 970 & 975 & 740 & 818 & 818 & 424 & 551 & 551 \\
\hline $\mathbf{2}$ (canto) & 610 & 782 & 782 & 756 & 897 & 902 & 445 & 482 & 482 \\
\hline $\mathbf{3}$ (canto) & 683 & 792 & 792 & 698 & 818 & 818 & 450 & 535 & 535 \\
\hline $\mathbf{4}$ (canto) & 730 & 782 & 782 & 599 & 871 & 907 & 366 & 387 & 450 \\
\hline média & 704 & 832 & 833 & 698 & 851 & 861 & 421 & 489 & 505 \\
\hline desvio padrão & 77 & 93 & 95 & 71 & 40 & 50 & 39 & 74 & 47 \\
\hline $\begin{array}{c}\text { coeficiente de } \\
\text { variação }\end{array}$ & 0,11 & 0,11 & 0,11 & 0,10 & 0,05 & 0,06 & 0,09 & 0,15 & 0,09 \\
\hline
\end{tabular}

TABELA 5 - Valores de resistência do solo à penetração do penetrômetro (R, em kPa) em cavas de $1,70 \mathrm{~m}$

\begin{tabular}{|l|c|c|c|c|c|c|}
\hline \multicolumn{1}{|c|}{ cava } & \multicolumn{3}{|c|}{$\mathbf{3}$} & \multicolumn{3}{c|}{8} \\
\hline penetração & $6 \mathrm{~cm}$ & $9 \mathrm{~cm}$ & $12 \mathrm{~cm}$ & $6 \mathrm{~cm}$ & $9 \mathrm{~cm}$ & $12 \mathrm{~cm}$ \\
\hline leitura & $\mathrm{R}(\mathrm{kPa})$ & $\mathrm{R}(\mathrm{kPa})$ & $\mathrm{R}(\mathrm{kPa})$ & $\mathrm{R}(\mathrm{kPa})$ & $\mathrm{R}(\mathrm{kPa})$ & $\mathrm{R}(\mathrm{kPa})$ \\
\hline $\mathbf{1}$ (centro) & 673 & 865 & 865 & 194 & 446 & 598 \\
\hline $\mathbf{2}$ (raio de 30 cm) & 751 & 1072 & 1139 & 341 & 456 & 509 \\
\hline $\mathbf{3}$ (raio de 30 cm) & 626 & 901 & 943 & 430 & 624 & 630 \\
\hline $\mathbf{4}$ (raio de 30 cm) & 766 & 989 & 994 & 330 & 556 & 682 \\
\hline $\mathbf{5}$ (raio de 30 cm) & 559 & 834 & 922 & 367 & 472 & 477 \\
\hline $\mathbf{6}$ (raio de 60 cm) & 777 & 1057 & 1057 & 346 & 430 & 488 \\
\hline $\mathbf{7}$ (raio de 60 cm) & 647 & 974 & 1025 & 325 & 430 & 477 \\
\hline $\mathbf{8}$ (raio de 60 cm) & 632 & 1041 & 1108 & 304 & 399 & 420 \\
\hline $\mathbf{9}$ (raio de 60 cm) & 699 & 963 & 1010 & 199 & 341 & 498 \\
\hline média & 681 & 966 & 1007 & 315 & 462 & 531 \\
\hline $\begin{array}{c}\text { desvio padrão } \\
\text { coeficiente de } \\
\text { variação }\end{array}$ & 0,11 & 85 & 88 & 76 & 84 & 86 \\
\hline
\end{tabular}

Nota: Foi aberta uma terceira cava de diâmetro 1,70 m para a realização dos ensaios, no entanto, a capacidade do penetrômetro $(1550 \mathrm{kPa})$ foi insuficiente para medir a resistência. 
Os valores médios de resistência para a mesma penetração, em cada cava, são destacados na Tabela 6.

TABELA 6 - Valor médio de resistência em três profundidades diferentes

\begin{tabular}{|c|c|c|c|c|}
\hline cava & \multirow{2}{*}{$\begin{array}{c}\text { sucção } \\
\end{array}$} & \multicolumn{3}{|c|}{ Resistência média (kPa) } \\
\cline { 3 - 5 } & & $\mathbf{6} \mathbf{c m}$ & $\mathbf{9} \mathbf{c m}$ & $\mathbf{1 2} \mathbf{~ c m}$ \\
\hline 1 & 15 & 844 & 953 & 954 \\
\hline 2 & 17 & 805 & 869 & 878 \\
\hline 3 & 0 & 356 & 461 & 506 \\
\hline 4 & 12 & 704 & 832 & 833 \\
\hline 5 & 13 & 698 & 851 & 861 \\
\hline 6 & 0 & 421 & 489 & 505 \\
\hline 7 & 20 & 681 & 966 & 1007 \\
\hline 8 & 0 & 315 & 462 & 531 \\
\hline
\end{tabular}

A partir dos dados da Tabela 6 , foi obtido o gráfico "resistência média $\mathrm{x}$ penetração", em função da sucção, o qual é apresentado na Figura 4.1.

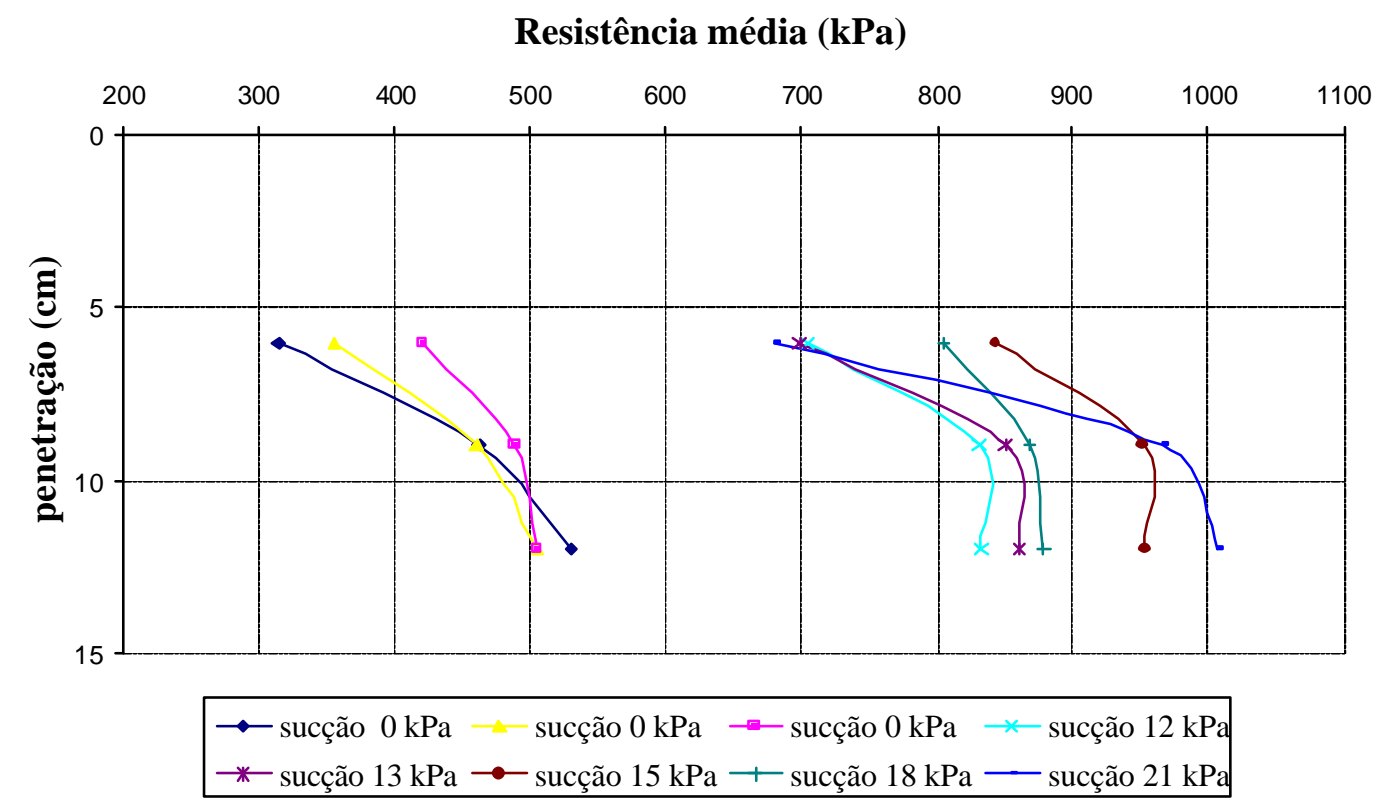

FIGURA 4.1 - Resistência média x penetração, em função da sucção 


\section{3-ANÁLISE DOS RESULTADOS}

\subsection{1 - Tensão de Ruptura do Ensaio Penetrométrico}

Da análise da Figura 4.1, observa-se que para a maioria dos ensaios, a partir de uma penetração de $9 \mathrm{~cm}$, o valor de resistência à penetração torna-se praticamente constante. Por isso, foi adotado como critério de ruptura convencional, a resistência correspondente à penetração de $9 \mathrm{~cm}$.

\subsection{2 - Variação da Tensão de Ruptura com a Sucção}

Determinando-se o valor de tensão de ruptura convencional $\left(\mathrm{q}_{\mathrm{p}}\right)$ do ensaio penetrométrico, tem-se a variação da tensão de ruptura em função da sucção $(\psi)$, apresentada na Figura 4.2, que consiste de uma razoável linearidade.

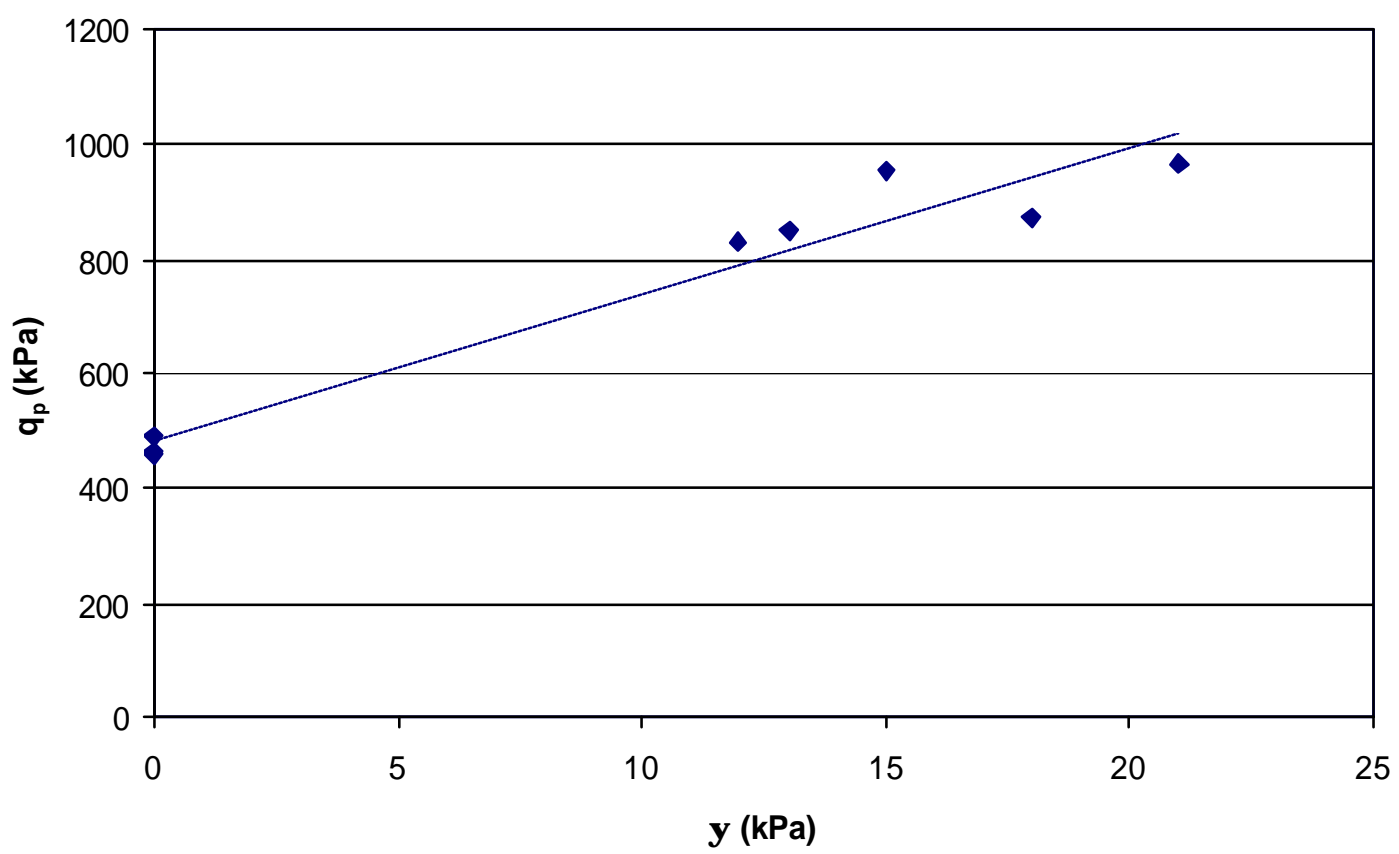

FIGURA 4.2 - Tensão de ruptura do ensaio penetrométrico $\left(q_{p}\right)$ x sucção $(\psi)$ 
Pelos pontos apresentados na Figura 4.2, obtém-se por regressão linear, a equação:

$$
\mathrm{q}_{\mathrm{p}}=25 \psi+487 \quad(\mathrm{kPa})
$$

com coeficiente $\mathrm{R}^{2}=0,944$.

A equação (1) pode ser utilizada para estimar a sucção no Campo Experimental de Fundações na USP de São Carlos, na profundidade de 1,50 m, quando se realizar o ensaio de penetração sem a correspondente monitoração da sucção. Ou, ao contrário, estimar a tensão de ruptura do ensaio penetrométrico a partir da sucção indicada pelo tensiômetro.

\subsection{3 - Comparação com Placas de Diâmetro 0,80 m}

Os resultados obtidos nos ensaios de penetração foram comparados com provas de carga realizadas por Costa (1999), em placa circular de 0,80 m de diâmetro, realizadas no Campo Experimental de Fundações da USP de São Carlos, à profundidade de 1,50 m, com monitoração de sucção.

Na Figura 4.3, são exibidas as curvas “tensão x recalque" obtidas por COSTA (1999), em dois ensaios inundados.

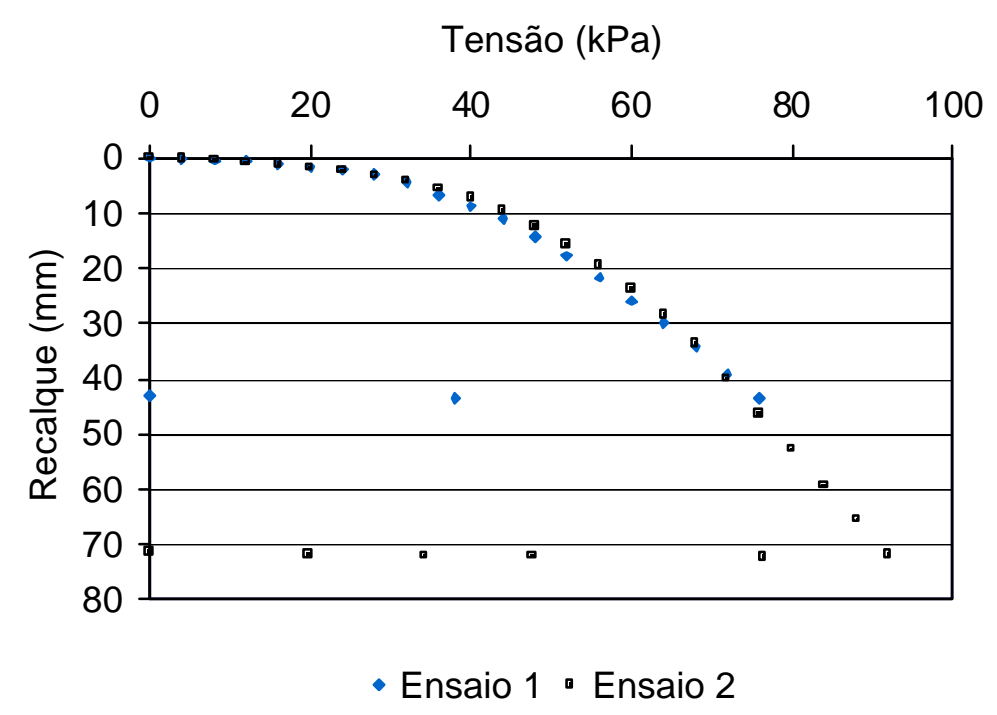

FIGURA 4.3 - Curvas "tensão x recalque" de dois ensaios inundados em placa de 0,80 m (COSTA, 1999) 
Na Figura 4.4, estão apresentadas as curvas “tensão x recalque", obtidas por COSTA (1999), em três ensaios de placa com os valores médios de sucção $(\psi)$ de: 15 , 22 e $33 \mathrm{kPa}$.

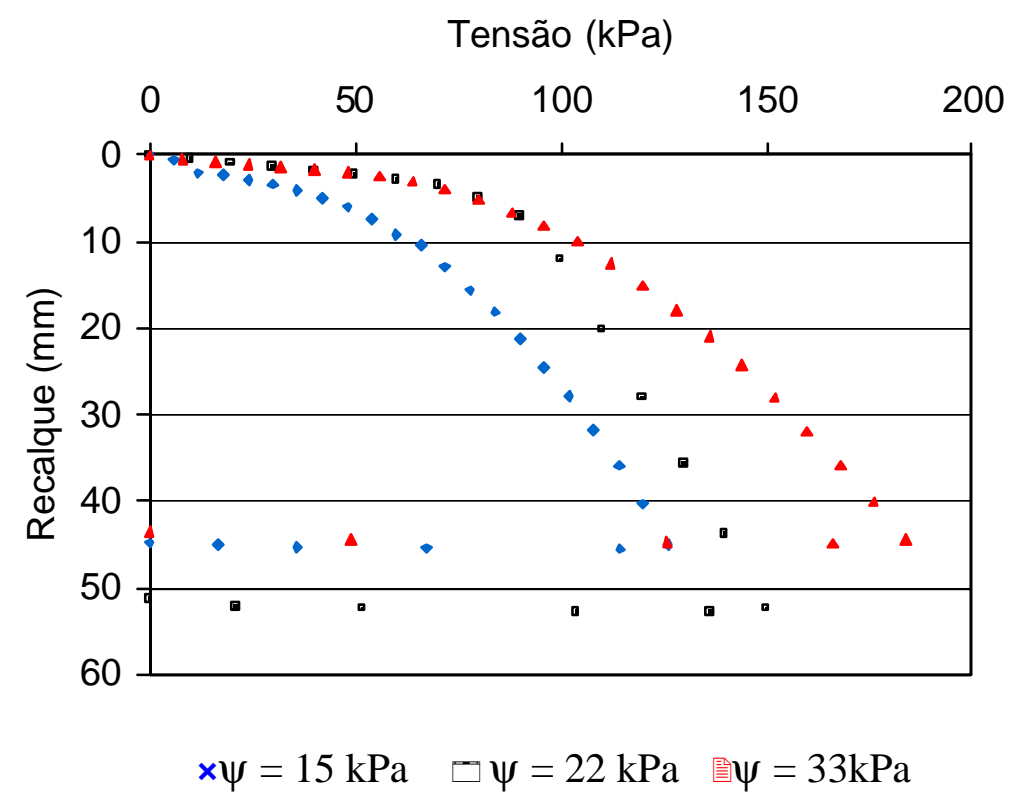

FIGURA 4.4 - Curvas "tensão x recalque" de três ensaios em placa de 0,80 m, com as sucções médias de 15, 22 e 33 kPa (COSTA, 1999)

A partir da equação (1), foi feita uma estimativa de valores de $\mathrm{q}_{\mathrm{p}}$, correspondentes aos valores de sucção de COSTA (1999). Na Tabela 7 apresentam-se os valores de $q_{p}$ e $\psi$.

TABELA 7 - Valores estimados de tensão de ruptura em ensaios de penetração $\left(q_{p}\right)$ correspondentes aos valores de sucção $(\psi)$

\begin{tabular}{|c|c|}
\hline sucção & $\begin{array}{c}\text { Tensão de ruptura } \\
\psi(\mathrm{kPa})\end{array}$ \\
\hline 0 & 487 \\
\hline 15 & 862 \\
\hline 22 & 1037 \\
\hline 33 & 1312 \\
\hline
\end{tabular}


Simultaneamente foram aplicados três critérios de ruptura convencional para interpretar as curvas tensão x recalque das Figuras 4.3 e 4.4:

$1^{\circ}$ ) critério de Terzaghi (1943), em que a capacidade de carga do sistema placa-solo corresponde ao ponto a partir do qual a curva tensão x recalque passa a exibir um comportamento linear.

$2^{\circ}$ ) uma espécie de "tensão de pré-adensamento", determinada pelo critério de Pacheco Silva (1970) aplicado após a transformação para a escala logarítmica dos valores de tensão obtidos no ensaio de placa.

$3^{\text {o) }}$ tensão correspondente ao recalque de $\mathrm{D} / 30$, em que $\mathrm{D}$ é o diâmetro da placa, o que eqüivale a um recalque de $26,7 \mathrm{~mm}$ para a placa de $0,80 \mathrm{~m}$. Esse valor é bem próximo do recalque de $25 \mathrm{~mm}$, considerado por Teixeira e Godoy (1996) como o recalque definidor da tensão de ruptura convencional na interpretação de provas de carga em placa.

Os valores de capacidade de carga correspondentes aos três critérios são apresentados na Tabela 8.

TABELA 8 - Capacidade de carga $\left(\sigma_{\mathrm{r}}\right)$ em ensaios de placa em função da sucção

\begin{tabular}{|c|c|c|c|}
\hline $\begin{array}{c}\text { sucção } \\
\begin{array}{c}\psi \\
\mathrm{kPa}\end{array}\end{array}$ & $\begin{array}{c}\text { Terzaghi } \\
\sigma_{\mathrm{r}} \\
\mathrm{kPa}\end{array}$ & $\begin{array}{c}\text { "pré-adensamento" } \\
\sigma_{\mathrm{r}} \\
\mathrm{kPa}\end{array}$ & $\begin{array}{c}\mathrm{D} / 30 \\
\sigma_{\mathrm{r}} \\
\mathrm{kPa}\end{array}$ \\
\hline 0 & 60 & 58 & 62 \\
\hline 15 & 102 & 85 & 100 \\
\hline 22 & 100 & 100 & 118 \\
\hline 33 & 144 & 121 & 150 \\
\hline
\end{tabular}

Com os valores apresentados nas Tabelas 7 e 8, pode-se construir a Figura 4.5, relacionando, para um mesmo nível de sucção, os valores de tensão de ruptura $\left(\mathrm{q}_{\mathrm{p}}\right)$ com a capacidade de carga $\left(\sigma_{\mathrm{r}}\right)$, para cada um dos critérios. 


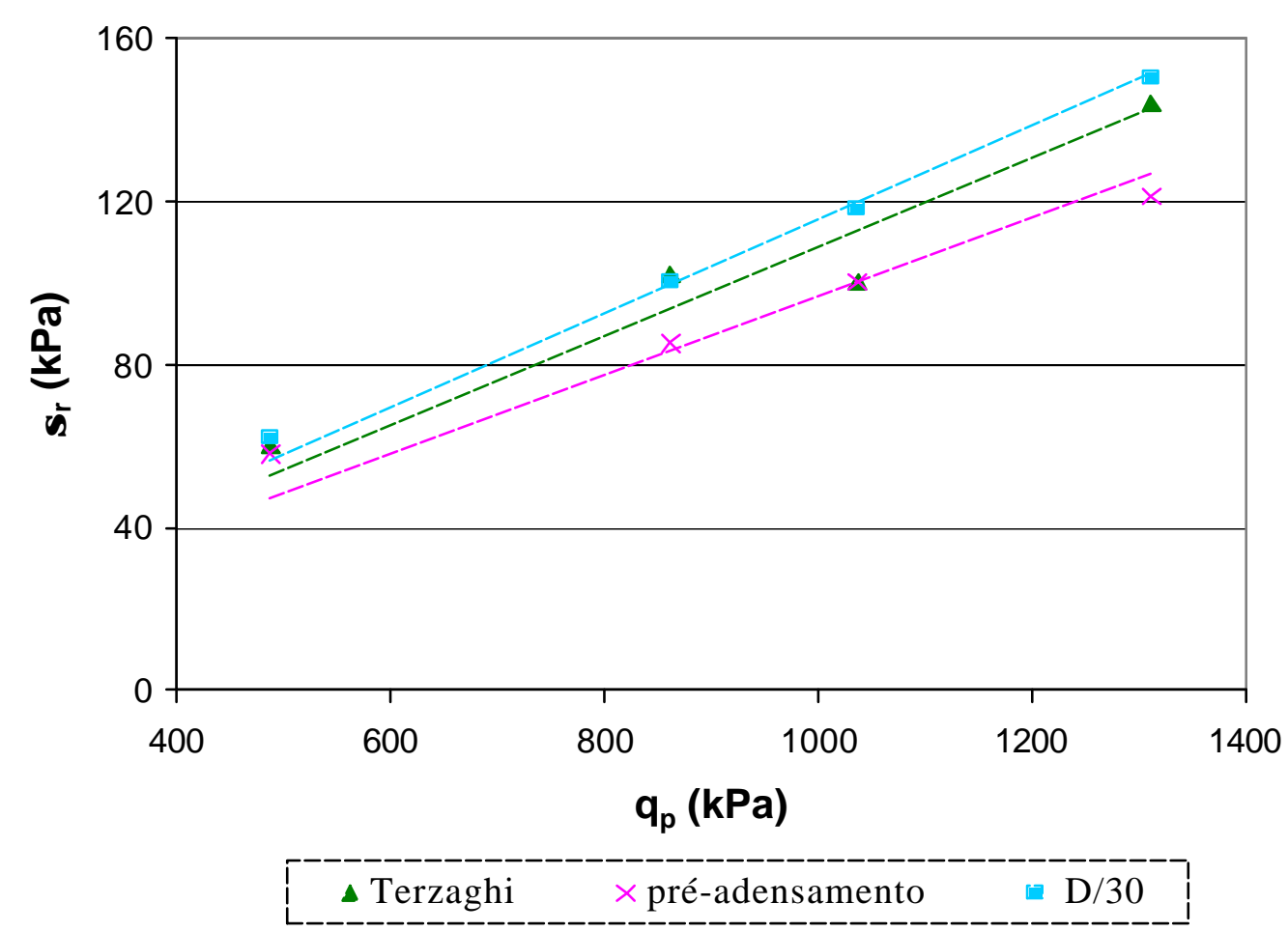

FIGURA 4.5 - Tensão de ruptura em ensaios de penetração $\left(\mathrm{q}_{\mathrm{p}}\right)$ x capacidade de carga $\left(\sigma_{\mathrm{r}}\right)$ em ensaios de placa de $\phi 0,80 \mathrm{~m}$, para um mesmo nível de sucção

Observando-se a existência de uma razoável linearidade entre os pontos relativos a um mesmo critério, determinoutse uma regressão linear para cada critério de ruptura convencional:

- critério de Terzaghi $\left(\mathrm{R}^{2}=0,920\right)$

$$
\begin{array}{lll}
\text { - critério de Terzaghi }\left(\mathrm{R}^{2}=0,920\right) & \sigma_{\mathrm{r}}=0,109 \mathrm{q}_{\mathrm{p}} & (\mathrm{kPa}) \\
\text { - critério “tensão de pré-adensamento" }\left(\mathrm{R}^{2}=0,926\right) & \sigma_{\mathrm{r}}=0,096 \mathrm{q}_{\mathrm{p}} & (\mathrm{kPa})
\end{array}
$$$$
\text { - critério } \mathrm{D} / 30\left(\mathrm{R}^{2}=0,990\right) \quad \sigma_{\mathrm{r}}=0,115 \mathrm{q}_{\mathrm{p}} \quad(\mathrm{kPa})
$$

Essas três equações podem ser representadas pela expressão:

$$
\sigma_{\mathrm{r}}=\alpha \mathrm{q}_{\mathrm{p}} \quad(\mathrm{kPa}), \operatorname{com} \alpha=0,105 \pm 0,010
$$


Para $\alpha=0,105$ e utilizando a equação (1), pode-se correlacionar a capacidade de carga diretamente com a sucção:

$$
\sigma_{\mathrm{r}}=2,6 \psi+51(\mathrm{kPa})
$$

\subsection{4 - Comparação com Sapatas de Diâmetro 1,50 m}

Os resultados obtidos nos ensaios de penetração também foram comparados com provas de carga em sapata realizadas por VIANNA \& CINTRA (2003), no Campo Experimental de Fundações da USP de São Carlos. Trata-se de sapata circular de 1,50 m de diâmetro, instalada em três cavas com diâmetro de 1,70 m, à profundidade de 1,50 m.

As provas de carga dessa sapata, cujas curvas tensão $\mathrm{x}$ recalque estão apresentadas na Figura 4.6, foram precedidas de ensaio de penetração no mesmo dia, nessas mesmas cavas (Tabela 5), para se trabalhar numa mesma pressão de sucção.

Tensão (kPa)

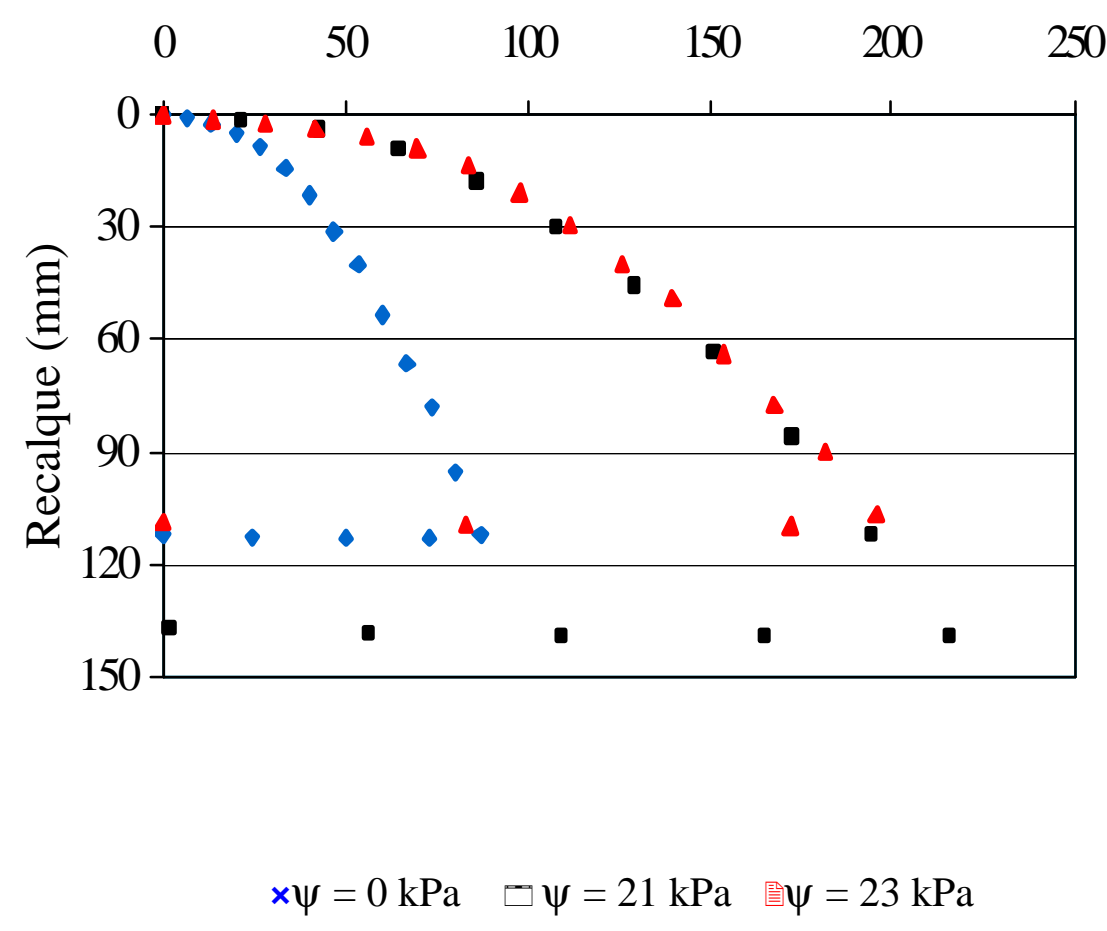

FIGURA 4.6 - Curvas "tensão x recalque" de três provas de carga em sapata de diâmetro 1,50 m, com as sucções médias de 0, 21 e $23 \mathrm{kPa}$ (VIANNA \& CINTRA, 2003) 
Na Tabela 9, apresentam-se os valores de sucção e de tensão de ruptura em ensaios de penetração $\left(\mathrm{q}_{\mathrm{p}}\right)$ medidos nas cavas em que concomitantemente foram feitas provas de carga em sapatas de diâmetro 1,50 m. Para a cava com sucção de $23 \mathrm{kPa}$, o valor de $\mathrm{q}_{\mathrm{p}}$ foi estimado pela equação (1), pois a capacidade do penetrômetro foi insuficiente para medir a resistência nesta cava.

TABELA 9 - Valores de sucção e de $\mathrm{q}_{\mathrm{p}}$ medidos no mesmo dia das provas de carga em sapata

\begin{tabular}{|c|c|}
\hline Sucção $\psi(\mathrm{kPa})$ & $\begin{array}{c}\text { tensão de ruptura em ensaio de } \\
\text { penetração } \mathrm{q}_{\mathrm{p}}(\mathrm{kPa})\end{array}$ \\
\hline 0 & 462 \\
\hline 21 & 966 \\
\hline 23 & $1062^{*}$ \\
\hline * O valor de $\mathrm{q}_{\mathrm{p}}$ foi estimado pela equação $(1)$.
\end{tabular}

As provas de carga da Figura 4.6 foram interpretadas pelos três mesmos critérios utilizados para a placa de $0,80 \mathrm{~m}$, obtendo-se os valores apresentados na Tabela 10 .

TABELA 10 - Valores de capacidade de carga $\left(\sigma_{\mathrm{r}}\right)$ em provas de carga em sapatas de $1,50 \mathrm{~m}$ de diâmetro, em função da sucção

\begin{tabular}{|c|c|c|c|}
\hline $\begin{array}{c}\text { sucção } \\
\psi(\mathrm{kPa})\end{array}$ & $\begin{array}{c}\text { Terzaghi } \\
\sigma_{\mathrm{r}}(\mathrm{kPa})\end{array}$ & $\begin{array}{c}\text { "pré-adensamento" } \\
\sigma_{\mathrm{r}}(\mathrm{kPa})\end{array}$ & $\begin{array}{c}\mathrm{D} / 30 \\
\sigma_{\mathrm{r}}(\mathrm{kPa})\end{array}$ \\
\hline 0 & 54 & 60 & 58 \\
\hline 21 & 151 & 120 & 134 \\
\hline 23 & 140 & 126 & 140 \\
\hline
\end{tabular}

Com os valores das Tabelas 9 e 10, pode-se obter o gráfico da Figura 4.7, relacionando, para uma mesma sucção, os valores de tensão de ruptura $\left(\mathrm{q}_{\mathrm{p}}\right)$ com capacidade de carga $\left(\sigma_{\mathrm{r}}\right)$, para os três critérios de ruptura convencional. 


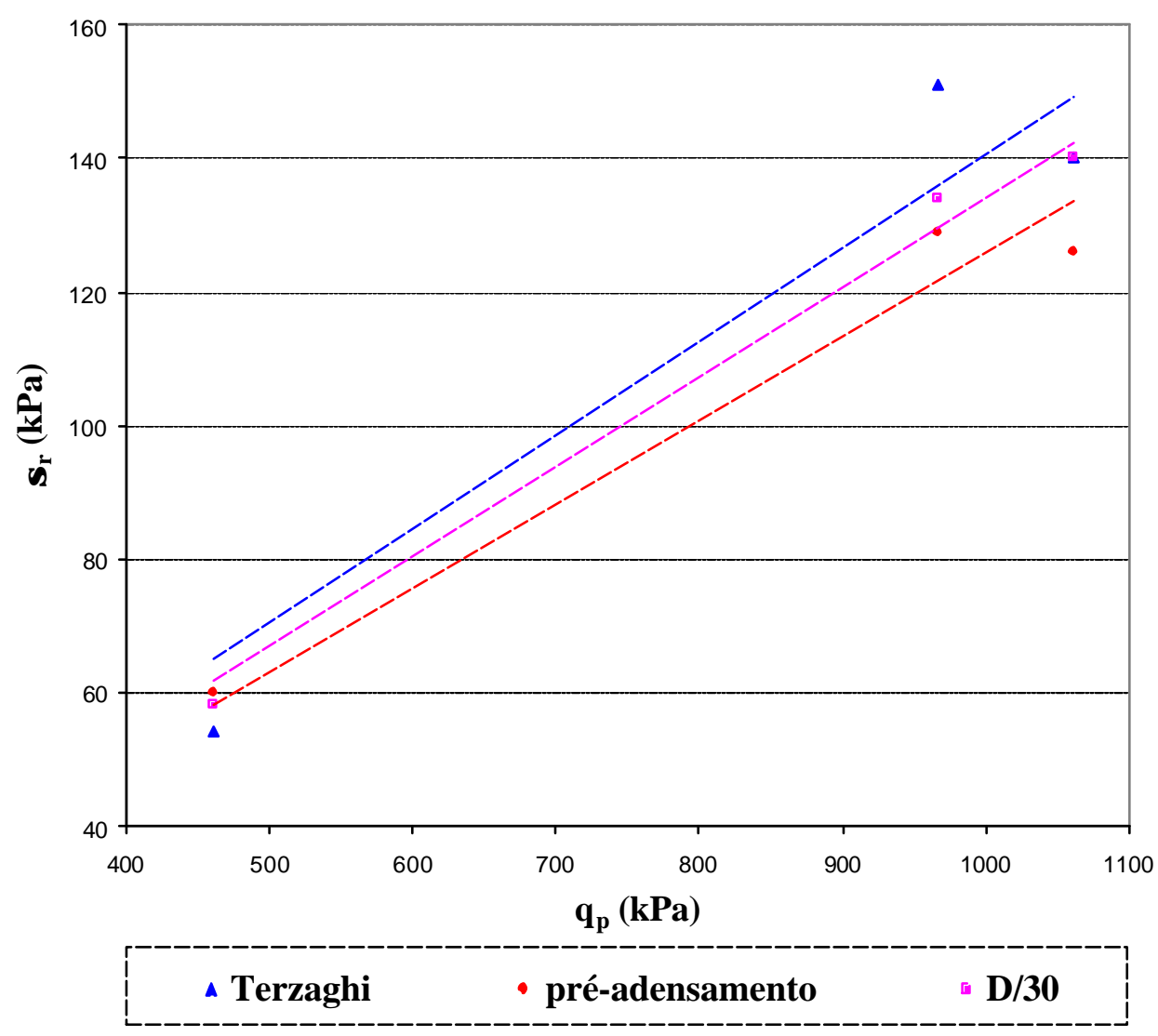

FIGURA 4.7 - Tensão de ruptura do penetrômetro $\left(\mathrm{q}_{\mathrm{p}}\right)$ x capacidade de carga $\left(\sigma_{\mathrm{r}}\right)$ do sistema sapata-solo, para uma mesma sucção

A partir dos pontos apresentados na Figura 4.7, pode-se obter uma regressão linear, para cada critério de ruptura convencional:

- critério de Terzaghi $\left(\mathrm{R}^{2}=0,922\right)$

$\sigma_{\mathrm{r}}=0,140 \mathrm{q}_{\mathrm{p}} \quad(\mathrm{kPa})$

- critério "tensão pré-adensamento" $\left(\mathrm{R}^{2}=0,961\right)$

$\sigma_{\mathrm{r}}=0,126 \mathrm{q}_{\mathrm{p}} \quad(\mathrm{kPa})$

- critério $\mathrm{D} / 30\left(\mathrm{R}^{2}=0,990\right)$ $\sigma_{\mathrm{r}}=0,134 \mathrm{q}_{\mathrm{p}} \quad(\mathrm{kPa})$

Essas três equações podem ser genericamente representadas pela expressão:

$$
\sigma_{\mathrm{r}}=\alpha \mathrm{q}_{\mathrm{p}} \quad(\mathrm{kPa}), \operatorname{com} \alpha=0,135 \pm 0,010
$$


Para $\alpha=0,135$ e utilizando a equação (1), pode-se correlacionar a capacidade de carga diretamente com a sucção:

$$
\sigma_{\mathrm{r}}=3,4 \psi+66(\mathrm{kPa})
$$

\subsection{5 - Comparação entre Placa e Sapata}

Atribuindo-se diferentes valores à sucção $(\psi)$ na equação (1) e substituindo-se os correspondentes valores de $\mathrm{q}_{\mathrm{p}}$ nas equações (2) a (7), é possível prever a capacidade de carga (critérios de Terzaghi, "tensão de pré-adensamento" e D/30) nos casos de placa e de sapata. Os resultados obtidos são representados na Tabela 11 , variando-se $\psi$ de 5 em 5 $\mathrm{kPa}$ até $30 \mathrm{kPa}$.

TABELA 11 - Valores de $q_{p}$ (tensão de ruptura em ensaio de penetração) e de $\sigma_{\mathrm{r}}$ (capacidade de carga em provas de carga em placa de 0,80 m e sapata de 1,50 m) para diferentes valores de sucção

\begin{tabular}{|c|c|c|c|c|c|c|c|}
\hline \multirow{2}{*}{$\begin{array}{c}\text { sucção } \\
\psi \\
(\mathrm{kPa})\end{array}$} & \multirow{2}{*}{$\begin{array}{c}\text { tensão de ruptura em } \\
\text { ensaio de penetração } \\
q_{p} \\
(\mathrm{kPa})\end{array}$} & \multicolumn{2}{|c|}{$\begin{array}{l}\text { Terzaghi } \\
\sigma_{\mathrm{r}}(\mathrm{kPa}) \\
\end{array}$} & \multicolumn{2}{|c|}{$\begin{array}{c}\text { "pré-adensamento" } \\
\sigma_{\mathrm{r}}(\mathrm{kPa})\end{array}$} & \multicolumn{2}{|c|}{$\begin{array}{c}\mathrm{D} / 30 \\
\sigma_{\mathrm{r}}(\mathrm{kPa}) \\
\end{array}$} \\
\hline & & $0,80 \mathrm{~m}$ & $1,50 \mathrm{~m}$ & $0,80 \mathrm{~m}$ & $1,50 \mathrm{~m}$ & $0,80 \mathrm{~m}$ & $1,50 \mathrm{~m}$ \\
\hline 0 & 487 & 53 & 68 & 47 & 61 & 56 & 65 \\
\hline 5 & 612 & 67 & 86 & 59 & 77 & 70 & 82 \\
\hline 10 & 737 & 80 & 103 & 71 & 93 & 85 & 99 \\
\hline 15 & 862 & 94 & 121 & 83 & 109 & 99 & 116 \\
\hline 20 & 987 & 108 & 138 & 95 & 124 & 114 & 132 \\
\hline 25 & 1112 & 121 & 156 & 107 & 140 & 128 & 149 \\
\hline 30 & 1237 & 135 & 173 & 119 & 156 & 142 & 166 \\
\hline
\end{tabular}

A partir dos valores da Tabela 11, ou da comparação das equações 2 a 4 com as equações 5 a 7 , pode-se quantificar a majoração da capacidade de carga ao se passar da placa de $0,80 \mathrm{~m}$ para a sapata de $1,50 \mathrm{~m}$, na mesma sucção. Essa majoração é de $28 \%$ para o critério de Terzaghi, de $30 \%$ para o critério de "tensão de pré-adensamento", e de $16 \%$ para o critério $\mathrm{D} / 30$. 


\subsection{6 - Influência da Colapsibilidade}

Com base na equação (1) ou na Tabela 11, pode-se constatar que a sucção influencia significativamente a tensão de ruptura do ensaio penetrométrico. Por exemplo, o valor de $\mathrm{q}_{\mathrm{p}}$ correspondente à sucção de $20 \mathrm{kPa}$ é o dobro do valor de $\mathrm{q}_{\mathrm{p}}$ para a sucção igual a zero. Ou, de modo inverso, ao passar da sucção de $20 \mathrm{kPa}$ para a condição inundada, tem-se uma redução de $50 \%$ da tensão de ruptura do ensaio de penetração.

De modo semelhante, a Tabela 11 também indica que independente do critério de ruptura adotado, tanto para a placa de $0,80 \mathrm{~m}$ como para a sapata de $1,50 \mathrm{~m}$, a capacidade de carga dobra de valor ao passar da sucção nula para sucção de $20 \mathrm{kPa}$. Ou, inversamente, ocorre uma redução de $50 \%$ na capacidade de carga ao se inundar o solo que estava em condição de sucção correspondente a $20 \mathrm{kPa}$.

Comparando apenas os resultados dos ensaios inundados, observa-se que a capacidade de carga é praticamente a mesma na placa de 0,80 m e na sapata de 1,50 m. Para a placa, os valores variam de $58 \mathrm{kPa}$ a $62 \mathrm{kPa}$ e, na sapata, de $54 \mathrm{kPa}$ a $60 \mathrm{kPa}$, dependendo do critério de interpretação (Tabelas 8 e 10, respectivamente). Assim, para a sucção nula parece não haver influência da dimensão na capacidade de carga, considerando-se a dimensão mínima de 0,80 m.

Para a sucção nula, os valores de tensão de ruptura obtidos no ensaio penetrométrico são de $482 \mathrm{kPa}$ e $465 \mathrm{kPa}$ (Tabelas 7 e 9, respectivamente). Assim, no caso particular de sucção nula, pode-se estabelecer uma correlação entre capacidade de carga e tensão de ruptura independentemente da dimensão:

$$
\sigma_{\mathrm{r}} \cong 0,125 \mathrm{qp}_{\mathrm{p}}
$$

em que:

$\sigma_{\mathrm{r}}=$ capacidade de carga para placas de diâmetro $0,80 \mathrm{~m}$ e sapatas de diâmetro 1,50 m $\mathrm{q}_{\mathrm{p}}=$ tensão de ruptura do ensaio penetrométrico 
CAPÍTULO 05

\section{CONCLUSÕES E RECOMENDAÇÕES}

Neste capítulo, apresentam-se as principais conclusões sobre a utilização de um penetrômetro portátil com anel dinamométrico, no Campo Experimental de Fundações da USP de São Carlos, em cavas abertas até a profundidade de 1,50 m, com monitoramento de sucção.

Os resultados desses ensaios penetrométricos são comparados aos de provas de carga em placas de 0,80 m de diâmetro e em sapatas de 1,50 m de diâmetro, realizados no mesmo locale à mesma profundidade.

\section{a) Ensaios penetrométricos}

É suficiente a realização de um mínimo de quatro ensaios penetrométricos por cava. A partir de quatro ensaios, o coeficiente de variação dos valores de resistência à penetração apresenta-se praticamente constante. Esse coeficiente de variação é da ordem de $10 \%$ nas cavas não inundadas e de $20 \%$ nas cavas inundadas.

Os valores para a tensão de ruptura do ensaio penetrométrico variam com a sucção, desde cerca de $500 \mathrm{kPa}$ para sucção nula até cerca de $1250 \mathrm{kPa}$ para sucção de $30 \mathrm{kPa}$.

Constata-se que a tensão de ruptura no ensaio de penetração, em função da sucção do solo, é praticamente linear, e pode ser expressa pela expressão:

$$
\mathrm{q}_{\mathrm{p}}=25 \psi+487(\mathrm{kPa}), \text { com } \mathrm{R}^{2}=0,944
$$

em que $q_{p}$ é tensão de ruptura $(\mathrm{kPa})$ medida pelo penetrômetro e $\psi$ é a sucção $(\mathrm{kPa})$ no momento do ensaio. Em conseqüência, é possível estimar valores de sucção a partir do ensaio penetrométrico, o que tem grande importância prática. 


\section{b) Placa de $0,80 \mathrm{~m}$ e sapata de $1,50 \mathrm{~m}$}

Para os três critérios de ruptura convencional ("Terzaghi”, "tensão de préadensamento", "tensão para o recalque de D/30") utilizados na interpretação das provas de carga em placa de 0,80 m e em sapata de 1,50 m, não houve variação significativa da capacidade de carga para um mesmo valor de sucção.

Nas provas de carga em placa de 0,80 m de diâmetro, a capacidade de carga varia de $60 \mathrm{kPa}$ para sucção nula até cerca de $140 \mathrm{kPa}$ para sucção de $30 \mathrm{kPa}$.

Para sapata de 1,50 m, esses valores variam de cerca de $60 \mathrm{kPa}$ a $170 \mathrm{kPa}$, para o intervalo de sucção de zero a $30 \mathrm{kPa}$.

\section{c) Influência da colapsibilidade}

A partir dos ensaios penetrométricos e das provas de carga analisadas neste trabalho, pode-se comprovar que a sucção apresenta importante influência no valor da tensão de ruptura do ensaio penetrométrico e nos valores da capacidade de carga de provas de carga em placa de $0,80 \mathrm{~m}$ e em sapata de $1,50 \mathrm{~m}$.

Ao se inundar o solo que estava inicialmente na condição de sucção correspondente a $20 \mathrm{kPa}$, por exemplo, encontra-se uma redução de $50 \%$ tanto da tensão de ruptura quanto da capacidade de carga .

\section{d) Tensão de ruptura em ensaio de penetração $\left(q_{p}\right)$ e capacidade de carga em provas de carga $\left(\sigma_{\mathbf{r}}\right)$}

Para uma mesma sucção, foram estabelecidas correlações entre $q_{p}$ e $\sigma_{r}$, do tipo:

$$
\sigma_{\mathrm{r}}=\alpha \mathrm{q}_{\mathrm{p}}
$$

com $\alpha=0,105 \pm 0,010$ para placa, e $\alpha=0,135 \pm 0,010$ para a sapata, dependendo do critério de interpretação de provas de carga.

Em conseqüência, é possível estimar valores de tensão de ruptura de provas de carga em placa de $0,80 \mathrm{~m}$ e em sapata de $1,50 \mathrm{~m}$, a partir do ensaio penetrométrico, considerando o mesmo nível de sucção. No caso particular de sucção nula, a correlação 
entre tensão de ruptura do ensaio penetrométrico $\left(\mathrm{q}_{\mathrm{p}}\right)$ e capacidade de carga $\left(\sigma_{\mathrm{r}}\right)$ independe da dimensão:

$$
\sigma_{\mathrm{r}} \cong 0,125 \mathrm{qp}_{\mathrm{p}}
$$

tanto para placas de $0,80 \mathrm{~m}$ como para sapatas de $1,50 \mathrm{~m}$.

\section{e) Comparação entre placa de 0,80 m e sapata de $1,50 \mathrm{~m}$}

Ao passar da placa de 0,80 m de diâmetro para a sapata de 1,50 m de diâmetro, ocorre uma majoração na capacidade de carga de cerca de 20 a 30\%, dependendo do critério de interpretação, para provas de carga realizadas sem inundação do solo, mas na mesma sucção.

Para a sucção nula, não ocorre essa majoração de capacidade de carga ao se passar da placa de $0,80 \mathrm{~m}$ para a sapata de $1,50 \mathrm{~m}$.

\section{f) Recomendações}

É recomendável a utilização de pontas de penetrômetro com diferentes diâmetros, para que, quando forem realizados ensaios em solos mais resistentes, seja possível a penetração da ponta.

Sugere-se também:

- realização do ensaio penetrométrico e de placa em outros tipos de solo, para se verificar a variação nas correlações entre tensão de ruptura e capacidade de carga.

- realização de provas de carga em sapatas maiores para definir melhor a influência da dimensão da sapata na capacidade de carga, em função da sucção.

Por fim, pesquisa semelhante a esta poderá ser feita, com ensaios a maiores profundidades, com vistas a uma eventual aplicação para fundação por tubulões. 


\section{REFERÊNCIAS BIBLIOGRÁFICAS}

ABGE - ASSOCIAÇÃO BRASILEIRA DE GEOLOGIA DE ENGENHARIA (1980). Glossário de Equipamentos de Sondagens.

ABNT - ASSOCIAÇÃO BRASILEIRA DE NORMAS TÉCNICAS (1996). NBR-6122 - Projeto e Execução de Fundações. Rio de Janeiro, 33p.

ABNT - ASSOCIAÇÃO BRASILEIRA DE NORMAS TÉCNICAS (1984). NBR-6489 - Prova de Carga Direta Sobre Terreno de Fundação. Rio de Janeiro, 2p.

AOKI, N. (1973). Ensaio Holandês de Penetração. Curso de atualização em fundações. Centro de produção da UEG (CEPUEG).

AOKI, N. (2000). O futuro da engenharia de fundações. Palestra no Clube da Engenharia, Rio de Janeiro/RJ, Novembro.

CASTEllO, R. R.; POLIDO, U. F.; BICAlHO K. V.; RIBEIRO R. C. H. (2001). Recalques Observados de Sapatas em Solos Terciários de São Paulo. Solos e Rochas, São Paulo, 24, (2): 143-153, Maio-Agosto.

CINTRA, J.C.A. (1998) - "Fundações em solos colapsíveis”. Ed. Rima, São Carlos $\mathrm{SP}, 116 \mathrm{p}$.

CINTRA, J.C.A.; AOKI, N.; ALBIERO, J. H. (2003) - “Tensão admissível em fundações diretas". Ed. Rima, São Carlos - SP, 134 p. 
COSTA, Y.D.J. (1999) - "Estudo do comportamento de solo não-saturado através de provas de carga em placa”. Dissertação de mestrado, USP / São Carlos, 131 p.

GODOY, N. S.; TEIXEIRA, A. T. (1996). Análise, Projeto e Execução de Fundações Rasas. Fundação: Teoria e Prática, Hachich et al. (eds.), Ed. Pini Ltda., São Paulo, Cap.7, p.227-264.

FREDLUND, D. G.; RAHARDJO, H. (1993). Soil Mechanics for Unsaturated Soils, Cap.11, p.318. New York, John Wiley \& Sons.

LOBO, A. S.; FERREIRA, C. V.; ALBIERO, J. H. (1994). Utilização do Penetrômetro Portátil. $2^{\circ}$ Simpósio sobre Solos Não Saturados, Recife, PE, p.253-258.

LOBO, A. S.; FERREIRA, C. V.; ALBIERO, J. H.; MARTINS A. G. R. (1996). Penetrômetro Portátil - Novas Correlações. $3^{\circ}$ Seminário de Engenharia de Fundações Especiais e Geotecnia - SEFE III, p.89-94.

MACACARI, M. F. (2001) - "Variação da capacidade de carga com a sucção e profundidade em ensaios de placa em solo colapsível”. Dissertação de mestrado, USP / São Carlos, 96 p.

PACHECO SILVA, F. (1970) - "Uma nova construção gráfica para a determinação da pressão de pré-adensamento de uma amostra de solos". COBRAMSEF, Rio de Janeiro, Vol II, Tomo I, p. 219-224.

RÖHM, S. A. (1984). Considerações sobre Penetrômetros Dinâmicos Leves Aplicados na Construção e Avaliação de pavimentos de Baixo Custo. Dissertação de mestrado EESC/USP. São Carlos, 109 p. 
SOLOTEST APARELHOS P/ MECÃNICA DO SOLO Ltda (2002), Catálogo de Produtos, São Paulo, Brasil.

TERZAGHI, K. (1943) - “Theoretical soil mechanics”. John Wiley and Sons Co., New York, $510 \mathrm{p}$.

VELLOSO, D. A.; LOPES, F. R. (1996). Fundações. Rio de Janeiro: COPPE/UFREJ, $281 \mathrm{p}$.

VIANNA, A. P.; CINTRA, J. C. A. (2003) - Bearing Capacity of Different Size Plates on Collapsible Soils. Symposium International sur les Fondations Superficielles, Paris, no prelo.

VILAR, O. M.; RODRIGUES, J. E.; NOGUEIRA J. B. (1981). Solos Colapsíveis: Um Problema para a Engenharia de Solos Tropicais. Anais I - Simpósio Brasileiro de Solos Tropicais em Engenharia, Rio de Janeiro, 1981. 


\section{ANEXO}

ANEXO A - Calibração de anel dinamométrico do penetrômetro da Solotest, utilizado nesta pesquisa, com capacidade nominal de $0,98 \mathrm{kN}$

\begin{tabular}{|c|c|c|c|c|c|c|c|c|}
\hline $\begin{array}{l}\text { Carga } \\
\text { Aplicada } \\
\text { em (N) }\end{array}$ & $\begin{array}{l}\text { Carga } \\
\text { Aplicada } \\
\text { em (kgf) }\end{array}$ & L1 & L2 & L3 & L - Média & Div/kgf & Repetibilidade $(\mathbf{\%})$ & $\begin{array}{l}\text { Incerteza } \\
\pm \text { kgf }\end{array}$ \\
\hline $\mathbf{0 , 0 0}$ & $\mathbf{0 , 0 0}$ & 0,00 & 0,00 & 0,00 & $\mathbf{0 , 0 0}$ & & & \\
\hline $\mathbf{9 8 , 0 0}$ & $\mathbf{1 0 , 0 0}$ & 27,50 & 28,00 & 28,00 & $\mathbf{2 7 , 8 3}$ & 2,78 & 5,00 & 0,73 \\
\hline $\mathbf{1 9 6 , 0 0}$ & $\mathbf{2 0 , 0 0}$ & 57,50 & 58,00 & 58,50 & $\mathbf{5 8 , 0 0}$ & 2,90 & 5,00 & 1,25 \\
\hline $\mathbf{2 9 4 , 0 0}$ & $\mathbf{3 0 , 0 0}$ & 87,00 & 88,00 & 88,00 & $\mathbf{8 7 , 6 7}$ & 2,92 & 3,33 & 1,48 \\
\hline $\mathbf{3 9 2 , 0 0}$ & $\mathbf{4 0 , 0 0}$ & 119,00 & 119,00 & 119,00 & $\mathbf{1 1 9 , 0 0}$ & 2,98 & 0,00 & 0,06 \\
\hline $\mathbf{4 9 0 , 0 0}$ & $\mathbf{5 0 , 0 0}$ & 148,00 & 149,00 & 149,00 & $\mathbf{1 4 8 , 6 7}$ & 2,97 & 2,00 & 1,50 \\
\hline $\mathbf{5 8 8 , 0 0}$ & $\mathbf{6 0 , 0 0}$ & 180,00 & 179,00 & 180,00 & $\mathbf{1 7 9 , 6 7}$ & 2,99 & 1,67 & 1,44 \\
\hline $\mathbf{6 8 6 , 0 0}$ & $\mathbf{7 0 , 0 0}$ & 211,00 & 211,00 & 211,00 & $\mathbf{2 1 1 , 0 0}$ & 3,01 & 0,00 & 0,22 \\
\hline $\mathbf{7 8 4 , 0 0}$ & $\mathbf{8 0 , 0 0}$ & 243,00 & 242,00 & 242,00 & $\mathbf{2 4 2 , 3 3}$ & 3,03 & 1,25 & 1,44 \\
\hline $\mathbf{8 8 2 , 0 0}$ & $\mathbf{9 0 , 0 0}$ & 274,00 & 274,00 & 273,00 & $\mathbf{2 7 3 , \mathbf { 6 7 }}$ & 3,04 & 1,11 & 1,44 \\
\hline $\mathbf{9 8 0 , 0 0}$ & $\mathbf{1 0 0 , 0 0}$ & 307,00 & 306,00 & 306,00 & $\mathbf{3 0 6 , 3 3}$ & 3,06 & 1,00 & 0,73 \\
\hline
\end{tabular}

Nota:

- Relógio posicionado em 0,000 mm para início da operação.

- $\quad$ Norma de referência : NBR 6674.

- $\mathrm{L}=$ Leitura no relógio comparador.

- Constante média do anel : 33,25 kgf/mm 